\title{
Systematic Review \\ The Influence of Vitamin D Intake and Status on Mental Health in Children: A Systematic Review
}

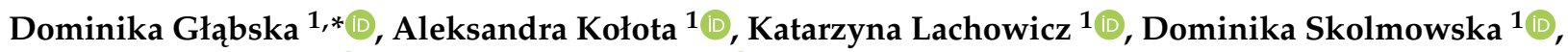 \\ Małgorzata Stachoń ${ }^{1}$ (D) and Dominika Guzek ${ }^{2}$ (D) \\ 1 Department of Dietetics, Institute of Human Nutrition Sciences, Warsaw University of Life \\ Sciences (WULS-SGGW), 159C Nowoursynowska Street, 02-776 Warsaw, Poland; \\ aleksandra_kolota@sggw.edu.pl (A.K.); katarzyna_lachowicz@sggw.edu.pl (K.L.); \\ dominika_skolmowska@sggw.edu.pl (D.S.); malgorzata_stachon@sggw.edu.pl (M.S.) \\ 2 Department of Food Market and Consumer Research, Institute of Human Nutrition Sciences, Warsaw \\ University of Life Sciences (WULS-SGGW), 159C Nowoursynowska Street, 02-776 Warsaw, Poland; \\ dominika_guzek@sggw.edu.pl \\ * Correspondence: dominika_glabska@sggw.edu.pl; Tel.: +48-22-593-71-26
}

check for updates

Citation: Głąbska, D.; Kołota, A.; Lachowicz, K.; Skolmowska, D.; Stachoń, M.; Guzek, D. The Influence of Vitamin D Intake and Status on Mental Health in Children: A Systematic Review. Nutrients 2021, 13, 952. https://doi.org/10.3390/ nu13030952

Academic Editors: Giovanni Passeri and Sandro Giannini

Received: 10 February 2021

Accepted: 12 March 2021

Published: 16 March 2021

Publisher's Note: MDPI stays neutral with regard to jurisdictional claims in published maps and institutional affiliations.

Copyright: (c) 2021 by the authors. Licensee MDPI, Basel, Switzerland. This article is an open access article distributed under the terms and conditions of the Creative Commons Attribution (CC BY) license (https:// creativecommons.org/licenses/by/ $4.0 /)$.
Abstract: A potential role of vitamin D in some components of mental health is currently suggested, but the analyses are conducted mainly for adults, while for young individuals mental health is especially important, due to its lifelong effects. The aim of the study was to analyze the association between vitamin $\mathrm{D}$ intake or status and mental health in children within a systematic review of literature, including both intervention and observational studies. The literature search was conducted according to the PRISMA guidelines and it covered peer-reviewed studies included in databases of PubMed and Web of Science until October 2019. The studies presenting either vitamin D intake, or vitamin D status in human subjects were allowed (excluding subjects with intellectual disabilities, eating disorders and neurological disorders), while for mental health the various methods of assessment and wide scope of factors were included. The bias was assessed using the Newcastle-Ottawa Scale (NOS). The review was registered in the PROSPERO database (CRD42020155779). A number of 7613 studies after duplicate removing were extracted by two independent researchers, followed by screening and assessment for eligibility, conducted by two independent researchers in two steps (based on title and abstract). Afterwards, the full texts were obtained and after reviewing, a number of 24 studies were included. The synthetic description of the results was prepared, structured around exposure (vitamin D supplementation/status) and outcome (components of mental health). The included studies were conducted either in groups of healthy individuals, or individuals with mental health problems, and they assessed following issues: behavior problems, violence behaviors, anxiety, depressive symptoms/depression, aggressive disorder, psychotic features, bipolar disorder, obsessive compulsive disorder, suicidal incident, as well as general patterns, as follows: mental health, level of distress, quality of life, well-being, mood, sleep patterns. The vast majority of assessed studies, including the most prominent ones (based on the NOS score) supported potential positive influence of vitamin D on mental health in children. As a limitation of the analysis, it should be indicated that studies conducted so far presented various studied groups, outcomes and psychological measures, so more studies are necessary to facilitate comparisons and deepen the observations. Nevertheless, vitamin D intake within a properly balanced diet or as a supplementation, except for a safe sun exposure, should be indicated as an element supporting mental health in children, so it should be recommended to meet the required $25(\mathrm{OH})$ cholecalciferol blood level in order to prevent or alleviate mental health problems.

Keywords: vitamin D; intake; status; supplementation; mental disorders; mental health; depression 


\section{Introduction}

The number of studies analyzing vitamin D status, relevance of its supplementation, as well as a link between this nutrient and clinical outcomes is currently increasing [1]. The knowledge about vitamin D is still broadening [2], but various serum 25-hydroxyvitamin D $(25(\mathrm{OH}) \mathrm{D})$ level thresholds are defined by prominent authorities as vitamin D deficiency, namely lower than $30 \mathrm{nmol} / \mathrm{L}[3,4]$ and lower than $50 \mathrm{nmol} / \mathrm{L}[5,6]$. The prevalence of vitamin D deficiency, depending on $25(\mathrm{OH}) \mathrm{D}$ level threshold is estimated as $13.0 \%$ and $40.4 \%$, respectively for 30 and $50 \mathrm{nmol} / \mathrm{L}$, irrespective of age group, ethnic mix, and latitude of study population [7]. In a vast majority of European countries, there is a common problem with achieving the recommended vitamin D status [8], except for Finland, due to high fish intake in this country, combined with food fortification and supplementation [9], which is applied within national program since 2003 in this country [10].

Such insufficient intake of vitamin D may result in a number of health-related consequences, including not only osteoporosis [11], but also other diseases and conditions. Recent meta-analyses indicated that vitamin D may reduce cancer mortality [12], as well as all-cause mortality [13]. Similarly, other meta-analyses emphasized its role for cardiac outcomes in coronary artery disease patients [14], prevention of diabetes [15] and prevention of acute respiratory infections [16], as well as experienced pain [17] and migraines [18]. Even for the COVID-19 it was stated that vitamin D may be associated with the risk [19] and severity of infection [20].

Among other diseases which are studied, as potentially influenced by vitamin D status, are those associated with broad area of mental health. The meta-analysis of randomized controlled trials by Cheng et al. [21] indicated that vitamin D supplementation can reduce negative emotions. Similarly, the systematic review by Hoffmann et al. [22] indicated that vitamin D supplementation may have a small to moderate effect on health-related quality of life, which was hypothesized by authors as resulting from widespread roles of this nutrient throughout the body and its association with many chronic diseases and mental health. At the same time, the meta-analyses by Gowda et al. [23] and by Li et al. [24] indicated that vitamin D supplementation did not cause significant reduction in depression. However, the meta-analysis by Spedding [25] indicated that such observations may result from biological flaws of primary studies, as in case of studies which he identified as those without biological flaws, he observed that vitamin D supplementation caused statistically significant improvement in depression. Similarly, the meta-analysis of randomized controlled trials by Vellekkatt and Menon [26] indicated that vitamin D supplementation favorably impacted depression ratings in major depression. Also the meta-analyses by Anglin et al. [27] and by Ju et al. [28] demonstrated that low vitamin D blood concentration may be associated with depression. At the same time, for the depressive symptoms, the meta-analysis by Shaffer et al. [29] indicated that vitamin D supplementation may be effective in reducing depressive symptoms in patients with clinically significant depression.

As indicated, there were some analysis conducted for effects of vitamin D on depression or depressive symptoms [23-29], as well as single studies for negative emotions [21] and for quality of life [22], but not for other aspects of the broad spectrum of mental health. According to the definition by the World Health Organization (WHO), mental health is interpreted as a state of well-being in which the individuals realize their own abilities, can cope with the normal stresses of life, can work productively and fruitfully, and are able to make a contribution to their community [30]. Based on the indicated scope of mental health, not only depression, negative emotions, or quality of life are commonly included while analyzing mental health, but also symptoms such as stress, nervousness, anxiety, self-efficacy, self-esteem, happiness, or general well-being, life satisfaction, and mood [31]. Moreover, it should be indicated that while there are some studies for adults, there are no such analysis conducted for children or adolescents, in spite of the fact that their mental health is especially important, as it has lifelong effects on individuals and society [32]. Some studies conducted so far revealed that children with psychiatric disorders might have 
higher prevalence of hypovitaminosis D than the general pediatric population [33] and that the association observed in adults may be also noticed in children and adolescents [34].

Based on the presented background, the aim of the study was to analyze the association between vitamin D intake or status and mental health in children within a systematic review of literature, including both intervention and observational studies.

\section{Materials and Methods}

\subsection{Design}

The literature search was conducted according to the guidelines of the Preferred Reporting Items for Systematic Reviews and Meta-Analyses (PRISMA) [35] and it covered peer-reviewed studies included in databases of PubMed and Web of Science until October 2019. The review was registered in the International Prospective Register of Systematic Reviews (PROSPERO) database (CRD42020155779).

\subsection{Inclusion and Exclusion Criteria}

The included observational studies presented association between vitamin $\mathrm{D}$ intake (either from diet or supplementation) and mental health in children. The inclusion criteria were as follows:

(1) studies conducted in children/adolescents;

(2) studies presenting vitamin $\mathrm{D}$ intake (either from diet or supplementation), or vitamin D status assessed (e.g., 25(OH)cholecalciferol blood level);

(3) studies presenting mental health, while various methods of assessment (e.g., medical diagnosis, questionnaire) and wide scope of factors associated with mental health were allowed.

The exclusion criteria were as follows:

(1) animal model studies;

(2) studies presenting influence of maternal vitamin D intake/status on mental health of their offspring;

(3) studies presenting influence of broad spectrum of nutrients combined;

(4) studies in participants with intellectual disabilities;

(5) studies in participants with eating disorders;

(6) studies in participants with neurological disorders (e.g., epilepsy).

The studies to be included were to be published in English in a peer-reviewed journal and were allowed to be conducted in any country, with no other criteria based on location or characteristics of the studied sample.

\subsection{Searching Strategy}

The literature searching covered intervention and observational studies included in databases of PubMed and Web of Science until October 2019. The search was based on the potential outcomes, commonly included to the systematic reviews [31]. The applied detailed electronic search strategy is presented in Table 1. As various outcomes were studied, the results of the systematic review were impossible to be reanalyzed as a metaanalysis, so synthetic description of results was prepared and structured around exposure (vitamin D intake/status) and outcome (components of mental health).

Identified studies after duplicate removing were extracted by two independent researchers followed by screening and assessment for eligibility, conducted by two independent researchers in two steps (to verify it separately based on title and in case of included, also based on abstract). If any disagreement appeared it was discussed with other researchers. Meanwhile, potentially eligible studies which were unavailable, were obtained by contacting the corresponding author of the study to ask them for a full text. Finally, the full texts were analyzed by two independent researchers. If any disagreement appeared it was discussed with other researchers. The detailed inclusion procedure is presented in Figure 1. 
Table 1. The applied detailed electronic search strategy for databases of PubMed and Web of Science.

\begin{tabular}{|c|c|}
\hline Database & The Applied Full Electronic Search Strategy \\
\hline PubMed & $\begin{array}{l}\text { (((mental health[T/A] OR mental disorders[T/A] OR mental disorder[T/A] OR psychological } \\
\text { distress[T/A] OR mood disorders[T/A] OR depression[T/A] OR suicidal[T/A] OR suicide[T/A] } \\
\text { OR anxiety[T/A] OR well-being[T/A] OR wellbeing[T/A] OR quality of life[T/A] OR self } \\
\text { esteem[T/A] OR self-esteem[T/A] OR self efficacy[T/A] OR self-efficacy[T/A] OR resilience[T/A] } \\
\text { OR empowerment[T/A] OR social participation[T/A] OR mental capital[T/A] OR life skills[T/A] } \\
\text { OR emotional[T/A] OR psychology[T/A] OR psychosocial[T/A] OR psychiatry[T/A])) AND } \\
\text { (vitamin D[T/A] OR vitamin D2[T/A] OR vitaminD3[T/A] OR D2[T/A] OR D3[T/A] OR } \\
\text { ergocalciferol[T/A] OR cholecalciferol[T/A] OR 25-hydroxyvitamin D[T/A] OR } \\
\text { 3-epi-25hydroxyvitaminD[T/A] OR calcitriol[T/A] OR dihydroxycholecalciferol[T/A])) NOT } \\
\text { (animal NOT (animal AND human)[MeSH Terms]) }\end{array}$ \\
\hline Web of Science & 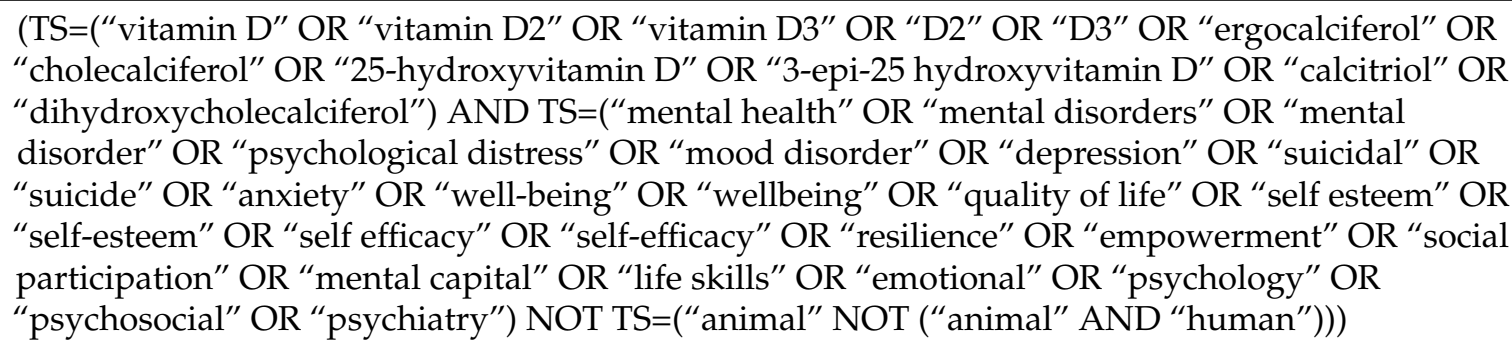 \\
\hline
\end{tabular}

T/A-Title/Abstract.
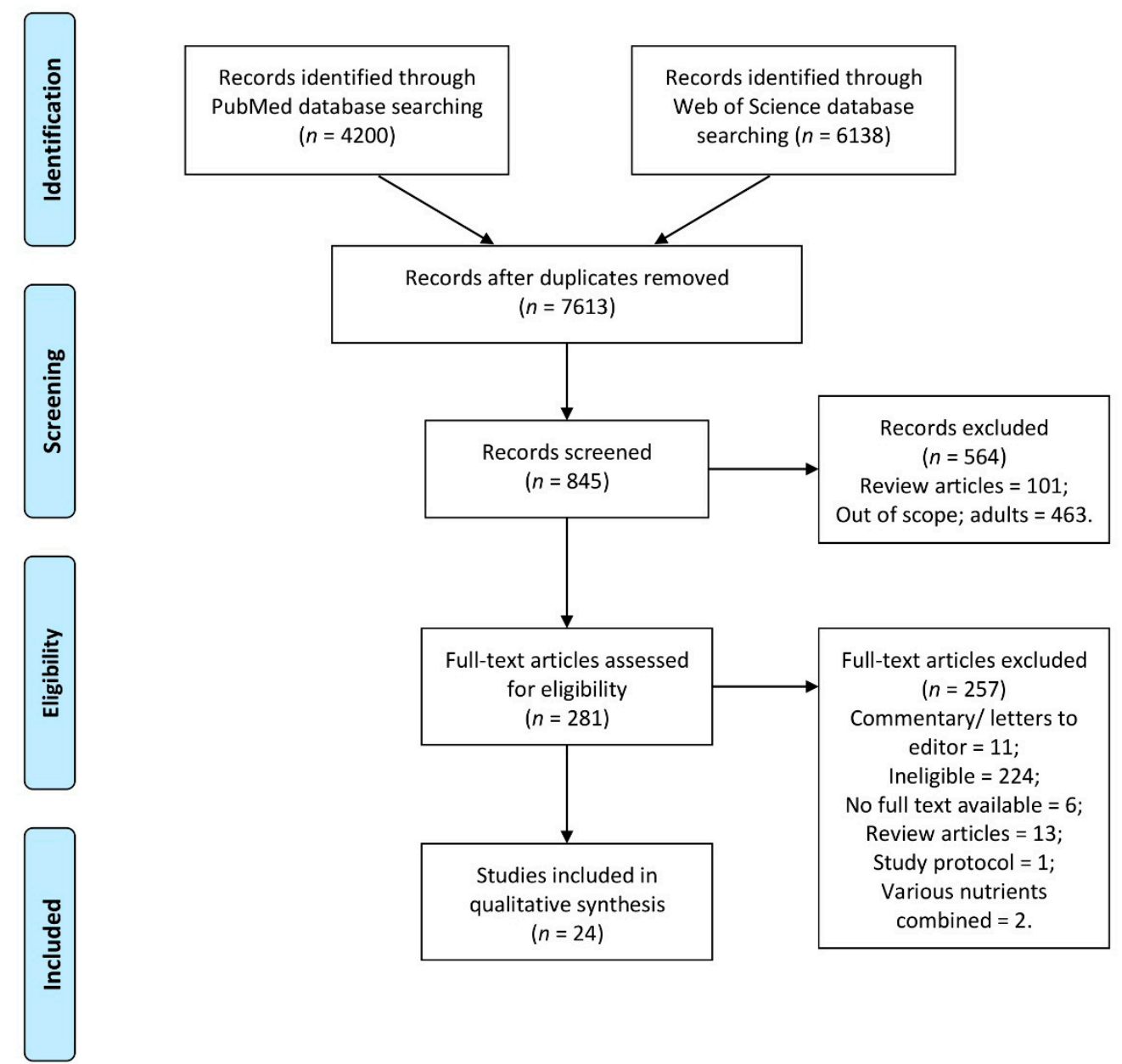

Figure 1. The detailed inclusion procedure in a systematic review of the literature. 
In case of one included study, due to the fact that it was presented as an abstract only [36], the manual search for the full text article was conducted to replace abstract by full text [37].

\subsection{Data Extraction Procedure}

The data extracting was conducted by two independent researchers. If any disagreement appeared it was discussed with other researchers. If any data were missing, they were requested by contacting the corresponding authors of the study to ask them for a detailed information. In case of data provided on request, they are referred in Results section as provided on request. The data were extracted based on the common approach to extract the following information:

(1) general characteristics of the study, including: authors, design of the study, country or region; studied group; studied period;

(2) participants of the study, including: number of participants, sex, age, inclusion and exclusion criteria;

(3) assessment of vitamin D intake, or status, including: applied supplementation, or method of assessment of vitamin D status;

(4) assessment of mental health, including: method of assessment, applied psychological measure;

(5) findings of the study, including: observations described by authors of the study; findings formulated by the authors of the study.

The risk of bias and methodological quality of the included studies was assessed as recommended based on the Cochrane guidelines [38] using the Newcastle-Ottawa Scale (NOS) [39]. The case control studies were assessed, including the following criteria: selection, comparability, and exposure, while cohort studies were assessed, including the following criteria: selection, comparability, and outcome. The total score was described while compared with the following categories: very high (from 0 to 3 points), high (from 4 to 6 points), and low risk of bias (from 7 to 9 points), as it is commonly applied [40].

\section{Results}

\subsection{Intervention Studies}

The basic characteristics of the included intervention studies [37,41-46], including design of study, location, studied group and time are described in Table 2. The included intervention studies were conducted in various countries-United States of America [37,45], Nordic countries [43,46], Iran [41,42] and Turkey [44]. Only one study described a single sex sample of adolescent girls [42], while other studies were conducted in a mixed populations of boys and girls of various age [37,41,43-46]. Moreover, a majority of intervention studies assessed a specific populations of children with a sickle cell disease [37], attention deficit hyperactivity disorder (ADHD) [41], autism spectrum disorders [44], bipolar spectrum disorders [45] and depression [46], being in some studies compared with control groups. 
Table 2. The basic characteristics of the included intervention studies, including study design, location, studied group and time.

\begin{tabular}{|c|c|c|c|c|c|}
\hline Ref. & Authors, Year & Design of Study & Location & Studied Group & Time \\
\hline [37] & $\begin{array}{l}\text { Dougherty et al., } \\
2020\end{array}$ & Randomized study & $\begin{array}{l}\text { United States of } \\
\text { America } \\
\text { (USA)/Philadelphia }\end{array}$ & $\begin{array}{l}\text { African } \\
\text { American } \\
\text { children aged } \\
\text { 5-20 years with } \\
\text { and without } \\
\text { sickle cell disease }\end{array}$ & $\begin{array}{l}\text { April } \\
\text { 2012-January } \\
2013\end{array}$ \\
\hline [41] & $\begin{array}{l}\text { Naeini et al., } \\
2019\end{array}$ & $\begin{array}{l}\text { Double-blind, } \\
\text { randomized, controlled } \\
\text { clinical trial }\end{array}$ & Iran/Isfahan & $\begin{array}{l}\text { Students aged } \\
6-13 \text { years with } \\
\text { ADHD }\end{array}$ & Not specified \\
\hline [42] & $\begin{array}{l}\text { Bahrami et al., } \\
2018\end{array}$ & $\begin{array}{l}\text { Longitudinal study with } \\
\text { intervention }\end{array}$ & $\begin{array}{l}\text { Iran/Mashhad and } \\
\text { Sabzevar }\end{array}$ & Adolescent girls & Not specified \\
\hline [43] & Grung et al., 2017 & $\begin{array}{l}\text { Randomized } \\
\text { double-blind placebo } \\
\text { control trial }\end{array}$ & Norway/Bergen & $\begin{array}{l}\text { Healthy } \\
\text { volunteers aged } \\
13-14 \text { years }\end{array}$ & $\begin{array}{l}\text { January- } \\
\text { April } \\
2014\end{array}$ \\
\hline [44] & Guler et al. 2016 & Intervention study & Turkey/Istanbul & $\begin{array}{l}\text { Children aged } \\
4-10 \text { years with } \\
\text { autism spectrum } \\
\text { disorders }\end{array}$ & $\begin{array}{l}\text { April 2014- } \\
\text { November } \\
2015\end{array}$ \\
\hline [45] & $\begin{array}{l}\text { Sikoglu et al., } \\
2015\end{array}$ & $\begin{array}{l}\text { Intervention study within } \\
\text { Child and Adolescents } \\
\text { NeuroDevelopment } \\
\text { Initiative (CANDI) at the } \\
\text { University of } \\
\text { Massachusetts Medical } \\
\text { School }\end{array}$ & USA/Massachusetts & $\begin{array}{l}\text { Children and } \\
\text { adolescents with } \\
\text { bipolar spectrum } \\
\text { disorders from } \\
\text { CANDI }\end{array}$ & Not specified \\
\hline [46] & $\begin{array}{l}\text { Högberg et al., } \\
2012\end{array}$ & Intervention study & Sweden & $\begin{array}{l}\text { Depressed } \\
\text { adolescents }\end{array}$ & Not specified \\
\hline
\end{tabular}

ADHD—Attention Deficit Hyperactivity Disorder.

The characteristics of the subjects of the included intervention studies are described in Table 3. The included intervention studies were conducted in samples of various size, differing from 35 [45] to 940 participants [42], while the inclusion and exclusion criteria were formulated to obtain required samples. For the vast majority of studies, the exclusion criteria included any condition that would interfere with planned vitamin D supplementation, including the previously applied supplementation [37,41-44], participation in any other study impacting serum 25(OH)cholecalciferol blood level [37], and any disorder interfering with the action, absorption, distribution, metabolism or excretion of vitamin D [45], or required being stably medicated if taking daily supplementation [45].

The exposure, intervention and outcome of the included intervention studies are described in Table 4. The included studies presented various models of intervention, mainly conducted for 3 months [37,41,43,44,46], but also 2 months [45] and 9 weeks [42], while applied vitamin D doses differed from $25 \mu \mathrm{g}$ per day [41] to $1250 \mu \mathrm{g}$ per week (179 $\mu \mathrm{g}$ per day) [42,44]. The observed outcomes were associated with depressive symptoms/depression [42,45], aggressive disorder [42], suicidal incident [45], as well as general patterns, as follows: mental health [41,43], quality of life [37], well-being [46], mood [45,46], sleep patterns [44], which were assessed while using dedicated psychological measures. 
Table 3. The characteristics of the subjects of the included intervention studies.

\begin{tabular}{|c|c|c|}
\hline Ref. & $\begin{array}{l}\text { Number of } \\
\text { Participants (Girls) }\end{array}$ & Age (Years) (Mean with SD) \\
\hline [37] & $44(22)$ & $\begin{array}{l}11.0 \pm 4.0 \text { for sickle cell disease group } \\
10.0 \pm 4.0 \text { for healthy group }\end{array}$ \\
\hline [41] & $71(12)$ & $\begin{array}{l}9.2 \pm 1.8 \text { for vitamin } D \text { supplementation } \\
\text { group } \\
9.0 \pm 1.2 \text { for placebo group }\end{array}$ \\
\hline
\end{tabular}

\section{Inclusion Criteria/Exclusion Criteria}

Inclusion: African American; aged 5-20 years; with and without sickle cell disease; recruited from the Comprehensive Sickle Cell Center at the Children's Hospital of Philadelphia (CHOP); healthy subjects from the $\mathrm{CHOP}$ network of primary care centers and the greater Philadelphia region

Exclusion: participation in another study impacting serum $25(\mathrm{OH})$ cholecalciferol $(25(\mathrm{OH}) \mathrm{D})$; pregnant or lactating females; other chronic conditions or use of medications affecting growth, dietary intake, or nutritional status; use of vitamin $\mathrm{D}$ to treat vitamin $\mathrm{D}$ deficiency; baseline elevated serum calcium concentration; taking supplements containing vitamin D; BMI > 85th percentile for age and sex; chronic transfusion therapy (for sickle cell disease group)

Inclusion: aged 6-13 years; diagnosed with ADHD

Exclusion: poor compliance; BMI > 25; any apparent chronic disease; intake of vitamin D supplement, omega 3 or zinc during the past two months; use of non-pharmacological treatments such as neurofeedback; play therapy; any vision or movement disabilities; inability to provide informed consent

[42] $940(940) \quad 14.6 \pm 1.5$

Inclusion: absence of any autoimmune, cardiovascular, metabolic bone, thyroid, parathyroid, or adrenal disorder/disease; absence of hepatic failure, kidney diseases, malabsorption, or cancer Exclusion: any anti-inflammatory, antidepressant, antidiabetic, or anti-obesity drugs; vitamin D or calcium supplementation; hormone therapy during the past 6 months

[43] $50(32) \quad 14.0 * \quad \begin{aligned} & \text { Inclusion: healthy; aged 13-14 years, recruited from two schools in the de } \\ & \text { Bergen } \\ & \text { Exclusion: using nutrient supplements (e.g., cod liver oil, multivitamins) }\end{aligned}$

Exclusion: using nutrient supplements (e.g., cod liver oil, multivitamins)

Inclusion: meeting the diagnostic criteria for autistic disorder according to the DSM-V (for autism spectrum disorder group); mentally and neurologically healthy (for control group); age and sex-matched control group

[44] $120(32)$

$7.1 \pm 1.5$ for autism spectrum disorder

group

$6.9 \pm 1.6$ for control group
Exclusion: history of metabolic disorder, systemic inflammatory disease, obesity; usage of antiepileptic drugs, steroids, estrogens, immune suppressors, bisphosphonates, calcium, and vitamin D 
Table 3. Cont

Number of

\section{Participants (Girls)}

Age (Years) (Mean with SD)$$
11.9 \pm 3.6 \text { for control group }
$$ \\ $11.9 \pm 3.6$ for control group}

\section{Inclusion Criteria/Exclusion Criteria}

Inclusion: children and adolescents from Child and Adolescents NeuroDevelopment Initiative (CANDI) at the University of Massachusetts Medical School; aged 6-17 years; being able ingest the vitamin D3 orally; the screen visit Young Mania Rating Scale (YMRS) score $\geq 8$ and the Clinical Global

Impressions-Severity Score (CGI-S) $\geq 3$ (for bipolar spectrum disorder group); if taking psychotropic medications, or daily multivitamin or vitamin supplement, stably medicated (same dose for 4 weeks prior

to enrolment and willing to do it within the study)

Exclusion: history of an uncontrolled general medical disorder; history of neurological illness,

schizophrenia, or psychosis; history of head trauma with loss of consciousness; substance dependence; suicidal or homicidal ideation; contraindications to magnetic resonance imaging; disorder that would interfere with the action, absorption, distribution, metabolism or excretion of vitamin D3, that might pose a safety concern, or interfere with the accurate assessment of safety and efficacy; axis I diagnosis or a family history of a mood disorder in a first degree (for control group)

Inclusion: depr
Exclusion: - 
Table 4. The exposure, intervention and outcome of the included intervention studies.

\begin{tabular}{|c|c|c|c|c|}
\hline Ref. & Exposure & Applied Intervention & Outcome & Psychological Measure \\
\hline [37] & $\begin{array}{l}25(\mathrm{OH}) \text { cholecalciferol } \\
\text { level in blood }\end{array}$ & $\begin{array}{l}\text { Vitamin D supplementation } \\
(100 \mu \mathrm{g} \text { vs. } 175 \mu \mathrm{g} \text { per day) } \\
\text { for } 3 \text { months }\end{array}$ & $\begin{array}{l}\text { Health-Related } \\
\text { Quality of Life }\end{array}$ & $\begin{array}{l}\text { PROMIS pediatric short } \\
\text { forms: depressive symptoms, } \\
\text { fatigue, pain, mobility, peer } \\
\text { relationships, and } \\
\text { upper-extremity function }\end{array}$ \\
\hline [41] & $\begin{array}{l}\text { Daily vitamin D } \\
\text { intake (Vit D-Food } \\
\text { record (FR)) } \\
25(\mathrm{OH}) \text { cholecalciferol } \\
\text { level in blood }\end{array}$ & $\begin{array}{l}\text { Vitamin D supplementation } \\
\text { ( } 25 \mu \mathrm{g} \text { per day vs. placebo) } \\
\text { for } 3 \text { months }\end{array}$ & Mental health & $\begin{array}{l}\text { Strengths and Difficulties } \\
\text { Questionnaire-Teacher } \\
\text { Version (SDQT), Strengths } \\
\text { and Difficulties } \\
\text { Questionnaire-Parent } \\
\text { Version (SDQP) }\end{array}$ \\
\hline [42] & $\begin{array}{l}25(\mathrm{OH}) \text { cholecalciferol } \\
\text { level in blood }\end{array}$ & $\begin{array}{l}\text { Vitamin D supplementation } \\
\text { ( } 1250 \mu \mathrm{g} \text { once a week) for } 9 \\
\text { weeks in intervention phase }\end{array}$ & $\begin{array}{l}\text { Depressive } \\
\text { symptoms } \\
\text { Aggressive disorder }\end{array}$ & $\begin{array}{l}\text { Beck Depression } \\
\text { Inventory-Persian version } \\
\text { (BDI Persian) } \\
\text { Buss-Perry Aggression } \\
\text { Questionnaire-Persian } \\
\text { version (BPAQ) }\end{array}$ \\
\hline [43] & $\begin{array}{l}25(\mathrm{OH}) \text { cholecalciferol } \\
\text { level in blood }\end{array}$ & $\begin{array}{l}\text { Vitamin D supplementation } \\
(38 \mu \mathrm{g} \text { per day) vs. control for } \\
3 \text { months }\end{array}$ & $\begin{array}{l}\text { Self-perception of } \\
\text { mental health }\end{array}$ & $\begin{array}{l}\text { Youth Self-report version of } \\
\text { the Child Behavior Checklist } \\
\text { (YSR-CBCL) }\end{array}$ \\
\hline [44] & $\begin{array}{l}25(\mathrm{OH}) \text { cholecalciferol } \\
\text { level in blood }\end{array}$ & $\begin{array}{l}\text { Ergocalciferol } \\
\text { supplementation, depending } \\
\text { on the vitamin D status } \\
(125 \mu \mathrm{g} \text { per day for patients } \\
\text { of } 25(\mathrm{OH}) \mathrm{D} \text { concentration of } \\
50-72.5 \mathrm{nmol} / \mathrm{L} \text { vs. } 1250 \mu \mathrm{g} \\
\text { per week for }<50 \mathrm{nmol} / \mathrm{L}) \\
\text { for } 3 \text { months }\end{array}$ & $\begin{array}{l}\text { Sleep patterns and } \\
\text { sleep problems }\end{array}$ & $\begin{array}{l}\text { Children's Sleep Habits } \\
\text { Questionnaire (CSHQ) }\end{array}$ \\
\hline [45] & $\begin{array}{l}25(\mathrm{OH}) \text { cholecalciferol } \\
\text { level in blood }\end{array}$ & $\begin{array}{l}\text { Vitamin D supplementation } \\
(50 \mu \mathrm{g} \text { per day) for } 2 \text { months }\end{array}$ & $\begin{array}{l}\text { Mood } \\
\text { Depression } \\
\text { Suicidal incident }\end{array}$ & $\begin{array}{l}\text { Young Mania Rating Scale } \\
\text { (YMRS) } \\
\text { Children's Depression Rating } \\
\text { Scale (CDRS) } \\
\text { Columbia-Suicide Severity } \\
\text { Rating Scale (CSSR-S) }\end{array}$ \\
\hline [46] & $\begin{array}{l}25(\mathrm{OH}) \text { cholecalciferol } \\
\text { level in blood }\end{array}$ & $\begin{array}{l}\text { Vitamin D supplementation } \\
\text { depending on the status (for } \\
\text { patients of } 25(\mathrm{OH}) \mathrm{D} \\
<60 \mathrm{nmol} / \mathrm{L}): 100 \mu \mathrm{g} \text { per day } \\
\text { for } 1 \text { month followed by } \\
50 \mu \mathrm{g} \text { per day for } 2 \text { months }\end{array}$ & $\begin{array}{l}\text { Well-being } \\
\text { Mood }\end{array}$ & $\begin{array}{l}\text { WHO-5 Well-being scale } \\
\text { Mood and Feelings } \\
\text { Questionnaire-Short } \\
\text { Version (MFQ-S) }\end{array}$ \\
\hline
\end{tabular}

The findings presented in the intervention studies are described in Table 5, based on the data presented by authors of the refereed studies as the most important ones. 
Table 5. The findings presented in the intervention studies included to the systematic review.

\begin{tabular}{|c|c|c|}
\hline Ref. & Observation & Conclusion \\
\hline [37] & $\begin{array}{l}\text { In subjects with SS sickle cell disease, significant reductions in pain, fatigue, and depressive } \\
\text { symptoms and improved upper-extremity function were observed. In healthy subjects, } \\
\text { significant reductions in fatigue and improved upper-extremity function were observed. }\end{array}$ & $\begin{array}{l}\text { Daily high-dose vitamin D supplementation for } \\
\text { African American children with SS sickle cell disease } \\
\text { improved HRQL. }\end{array}$ \\
\hline [41] & $\begin{array}{l}\text { The mean scores of the SDQP and SDQT showed a significant difference in the two groups } \\
\text { after intervention. }\end{array}$ & $\begin{array}{l}\text { Vitamin D supplementation improves some } \\
\text { behavioral problems. }\end{array}$ \\
\hline [42] & $\begin{array}{l}\text { There was a significant reduction on mild, moderate, and severe depression score. However, } \\
\text { vitamin D supplementation had no significant effect on aggression score. }\end{array}$ & $\begin{array}{l}\text { Results suggest that supplementation with vitamin } \\
\text { D may improve depressive symptoms among } \\
\text { adolescent girls, as assessed by questionnaire, but } \\
\text { not aggression score. }\end{array}$ \\
\hline [43] & $\begin{array}{l}\text { Multivariate data analysis showed that participants with low vitamin D status scored worse on } \\
\text { the Tower of London tests and the more difficult sub-tasks on the Tower of Hanoi tests. They } \\
\text { also had a tendency to report higher frequency of externalizing behavior problems and } \\
\text { attention deficit. }\end{array}$ & $\begin{array}{l}\text { The study indicates that vitamin } D \text { status in } \\
\text { adolescents may be important for both executive } \\
\text { functioning and mental health. }\end{array}$ \\
\hline [44] & $\begin{array}{l}\text { In ASD patients, there was a significant negative correlation between serum } 25(\mathrm{OH}) \mathrm{D} \text { levels } \\
\text { and the night waking subscale }(\mathrm{r}=-0.301, p=0.019) \text {. In control patients, there was a } \\
\text { significant negative correlation between serum } 25(\mathrm{OH}) \mathrm{D} \text { levels and daytime sleepiness } \\
\text { subscales }(\mathrm{r}=-0.269, p=0.038) \text {. }\end{array}$ & $\begin{array}{l}\text { The results indicate that it may be suitable to use } \\
25(\mathrm{OH}) \mathrm{D} \text { replacement therapy in ASD patients and } \\
\text { healthy individuals with sleep disturbances. }\end{array}$ \\
\hline [45] & $\begin{array}{l}\text { Following an } 8 \text { week vitamin D3 supplementation, in BSD patients, there was a significant } \\
\text { decrease in YMRS scores }(\mathrm{t}=-3.66, p=0.002, \mathrm{df}=15) \text { and CDRS scores }(\mathrm{t}=-2.93, p=0.01, \mathrm{df} \\
=15) \text {. }\end{array}$ & $\begin{array}{l}\text { Following an } 8 \text { week open label trial with vitamin } \\
\text { D3 supplementation, patients with BSD exhibited } \\
\text { improvement in their mood in conjunction with } \\
\text { their neurochemistry. }\end{array}$ \\
\hline [46] & $\begin{array}{l}\text { Basal } 25(\mathrm{OH}) \mathrm{D} \text { levels correlated positively with well-being }(p<0.05) \text {. After vitamin } \mathrm{D} \\
\text { supplementation, well-being increased }(p<0.001) \text { and there was a significant improvement in } \\
\text { eight of the nine items in the vitamin D deficiency scale: depressed feeling }(p<0.001) \text {, } \\
\text { irritability }(p<0.05) \text {, tiredness }(p<0.001) \text {, mood swings }(p<0.01) \text {, sleep difficulties }(p<0.01) \text {, } \\
\text { weakness }(p<0.01) \text {, ability to concentrate }(p<0.05) \text { and pain }(p<0.05) \text {. There was a significant } \\
\text { amelioration of depression according to the MFQ-S }(p<0.05) .\end{array}$ & $\begin{array}{l}\text { This study showed low levels of vitamin } D \text { in } \\
\text { depressed adolescents, positive correlation between } \\
\text { vitamin D and well-being, and improved symptoms } \\
\text { related to depression and vitamin D deficiency after } \\
\text { vitamin D supplementation. }\end{array}$ \\
\hline
\end{tabular}

ASD—Autism Spectrum Disorder; BSD—Bipolar Spectrum Disorders; CDRS—Children's Depression Rating Scale; HRQL—Health-Related Quality of Life; MFQ-S—Mood and Feelings Questionnaire-Short Version; SDQP-Strengths and Difficulties Questionnaire-Parent Version; SDQT—Strengths and Difficulties Questionnaire-Teacher Version; YMRS-Young Mania Rating Scale.

\subsection{Observational Studies}

The basic characteristics of the included observational studies [47-63], including study design, location, studied group and time are described in Table 6. The included observational studies were conducted in various countries-United States of America [51,59-61], United Kingdom [62,63], Germany [54,57], Turkey [52,53,56], China [48-50], as well as Colombia [47], Canada [55] and Iran [58]. All the studies were conducted in a mixed populations of boys and girls of various age [47-63]. Some observational studies assessed a specific populations of children with a stable asthma [48], on chronic hemodialysis or peritoneal dialysis [49], with depressive disorders [50], mood symptom changes and elevated symptoms of mania [51], obsessive-compulsive disorder [52,53], established mental health diagnosis [55], cystic fibrosis [59], major depressive disorder [60], and on acute mental health treatment [61], being in some studies compared with control groups.

The characteristics of the participants of the included observational studies are described in Table 7. The included observational studies were conducted in the samples of various size, differing from 36 [51] to 9068 participants [54], while the inclusion and exclusion criteria were formulated to obtain homogenic samples to obtain the aim of the study. In case of some studies, the exclusion criteria included the previously applied vitamin D supplementation [48,49,52].

The exposure, intervention and outcome of the included observational studies are described in Table 8 . The included studies presented the influence of $25(\mathrm{OH})$ cholecalciferol blood level on various mental health related outcomes. The observed outcomes were associated with behavior problems [47], violence behaviors [58], anxiety [49,53], depressive symptoms/depression [50-53,56,59,60,63], psychotic features [61], bipolar disorder [51], obsessive compulsive disorder [52,53], as well as general patterns, as follows: mental health $[54,55,62]$, level of distress $[57,58]$, quality of life $[48,57]$, which were assessed while using dedicated psychological measures.

The findings presented in the observational studies are described in Table 9, based on the data presented by authors of the refereed studies as the most important ones. 
Table 6. The basic characteristics of the included observational studies, including study design, location, studied group and time.

\begin{tabular}{|c|c|c|c|c|c|}
\hline Ref & Authors, Year & Design of Study & Location & Studied Group & Time \\
\hline [47] & Robinson et al., 2019 & $\begin{array}{l}\text { Prospective cohort study } \\
\text { within the Bogota School } \\
\text { Children Cohort }\end{array}$ & Colombia/Bogota & $\begin{array}{l}\text { Children aged } 5-12 \text { years randomly } \\
\text { selected from primary public schools } \\
\text { in Bogota }\end{array}$ & $\begin{array}{l}\text { February 2006; 2011-2015 } \\
\text { (follow-up) }\end{array}$ \\
\hline [48] & Bai \& Dai, 2018 & Case-control study & China & $\begin{array}{l}\text { Children with stable asthma } \\
\text { compared with controls }\end{array}$ & $\begin{array}{l}\text { January 2013-December } \\
2016\end{array}$ \\
\hline [49] & Han et al., 2018 & Cross-sectional study & China/Jiaxing & $\begin{array}{l}\text { Pediatric patients on chronic } \\
\text { hemodialysis or peritoneal dialysis }\end{array}$ & May 2013-June 2016 \\
\hline [50] & Huang et al., 2018 & Cross-sectional study & China/Zaozhuang & $\begin{array}{l}\text { Adolescents with or without } \\
\text { depressive disorders aged } 8-16 \text { years } \\
\text { from outpatient pediatric health care } \\
\text { centers }\end{array}$ & March 2016-May 2018 \\
\hline [51] & Petrov et al., 2018 & $\begin{array}{l}\text { Cross-sectional study within } \\
\text { National Institute of Mental } \\
\text { Health (NIMH) Longitudinal } \\
\text { Assessment of Manic } \\
\text { Symptoms (LAMS) study }\end{array}$ & $\begin{array}{l}\text { United States of America } \\
\text { (USA) }\end{array}$ & $\begin{array}{l}\text { Adolescents enrolled in the NIMH } \\
\text { LAMS study, which examines mood } \\
\text { symptom changes and elevated } \\
\text { symptoms of mania biannually }\end{array}$ & Not specified \\
\hline [52] & Yazici et al., 2018 & Prospective case-control study & Turkey/Elazı̆̆ & $\begin{array}{l}\text { Children and adolescents aged } \\
7-15 \text { years with obsessive-compulsive } \\
\text { disorder compared with controls }\end{array}$ & $\begin{array}{l}\text { February 2015-January } \\
2016\end{array}$ \\
\hline [53] & Esnafoğlu \& Yaman, 2017 & Case-control study & Turkey/Ordu & $\begin{array}{l}\text { Patients with obsessive-compulsive } \\
\text { disorder who attended the children } \\
\text { and adolescents psychiatry outpatient } \\
\text { clinic }\end{array}$ & $\begin{array}{l}\text { December 2014-February } \\
2016^{*}\end{array}$ \\
\hline$[54]$ & Husmann et al., 2017 & $\begin{array}{l}\text { Cross-sectional study based on } \\
\text { the population-based and } \\
\text { nation-wide German Health } \\
\text { Interview and Examination } \\
\text { Survey for Children and } \\
\text { Adolescents (KiGGS) study }\end{array}$ & Germany & $\begin{array}{l}\text { Children aged } 3-17.9 \text { participating in } \\
\text { the KIGGS study }\end{array}$ & May 2003-May 2006 \\
\hline
\end{tabular}


Table 6. Cont.

\begin{tabular}{|c|c|c|c|c|c|}
\hline Ref & Authors, Year & Design of Study & Location & Studied Group & Time \\
\hline [55] & MacDonald et al., 2017 & Retrospective medical chart review & Canada/Edmonton & $\begin{array}{l}\text { Children ( } 2-18 \text { years) with and without } \\
\text { established mental health diagnosis and } \\
\text { with an obesity }\end{array}$ & 2011-2014 \\
\hline [56] & Karabel et al., 2016 & Retrospective case-control study & Turkey/Diyarbakır & $\begin{array}{l}\text { Patients of Adolescent Clinic and Child } \\
\text { Psychiatry Clinic }\end{array}$ & Not specified \\
\hline [57] & Schäfer et al., 2016 & $\begin{array}{l}\text { Cross-sectional study based on the } \\
\text { population-based and nation-wide } \\
\text { German Health Interview and } \\
\text { Examination Survey for Children } \\
\text { and Adolescents (KiGGS) study }\end{array}$ & Germany & $\begin{array}{l}\text { Adolescents aged } 11-17 \text { participating in } \\
\text { the KIGGS study }\end{array}$ & May 2003-May 2006 \\
\hline [58] & Ataie-Jafari et al., 2015 & $\begin{array}{l}\text { Cross-sectional study within the } \\
\text { Childhood and Adolescence } \\
\text { Surveillance and PreventIon of } \\
\text { Adult Noncommunicable Disease } \\
\text { (CASPIAN III) study }\end{array}$ & Iran & $\begin{array}{l}\text { Children and adolescents aged } 10-18 \text { years } \\
\text { within CASPIAN III study }\end{array}$ & 2009-2010 \\
\hline [59] & Smith et al., 2014 & Cross-sectional study & USA/Buffalo & $\begin{array}{l}\text { Children aged } 7-17 \text { years with cystic } \\
\text { fibrosis }\end{array}$ & Spring of 2007 \\
\hline [60] & Fazeli et al., 2013 & Cross-sectional study & USA/Massachusetts & $\begin{array}{l}\text { Adolescents aged of } 12-18 \text { years with and } \\
\text { without major depressive disorder }\end{array}$ & $\begin{array}{l}\text { September 2007-December } \\
2009\end{array}$ \\
\hline [61] & Gracious et al., 2012 & Cross-sectional study & USA/Rochester & $\begin{array}{l}\text { Adolescents on acute mental health } \\
\text { treatment }\end{array}$ & October 2008-February 2010 \\
\hline [62] & Tolppanen et al., 2012 & $\begin{array}{l}\text { Longitudinal Study within the } \\
\text { Avon Longitudinal Study of } \\
\text { Parents and Children (ALSPAC) }\end{array}$ & $\begin{array}{l}\text { United Kingdom/South West } \\
\text { England }\end{array}$ & Children from the ALSPAC & $\begin{array}{l}\text { Children born 1991-1992 } \\
\text { observed at the age of 7,9 } \\
\text { and 11 (1998-1999; 2000-2001; } \\
\text { 2002-2003) }\end{array}$ \\
\hline [63] & Tolppanen et al., 2012 & $\begin{array}{l}\text { Longitudinal Study within the } \\
\text { Avon Longitudinal Study of } \\
\text { Parents and Children (ALSPAC) }\end{array}$ & $\begin{array}{l}\text { United Kingdom/South West } \\
\text { England }\end{array}$ & Children from the ALSPAC & $\begin{array}{l}\text { Children born 1991-1992 } \\
\text { observed at the age of } 10 \text { and } \\
13 \text { (2001-2002; 2004-2005) }\end{array}$ \\
\hline
\end{tabular}


Table 7. The characteristics of the subjects of the included observational studies.

\begin{tabular}{|c|c|c|c|}
\hline Ref. & $\begin{array}{l}\text { Number of Participants } \\
\text { (Girls) }\end{array}$ & Age (Mean with SD/Range) & Inclusion Criteria/Exclusion Criteria \\
\hline [47] & $273(146)$ & $\begin{array}{l}8.6 \pm 1.6 \text { (enrolment) } \\
14.7 \pm 1.7 \text { (follow-up) }\end{array}$ & $\begin{array}{l}\text { Inclusion: children aged } 5-12 \text { years; randomly selected from primary public schools in Bogota within the Bogota } \\
\text { School Children Cohort } \\
\text { Exclusion: outside the 11-18 years range at follow-up; missing data }\end{array}$ \\
\hline [48] & 246 & $\begin{array}{l}8.5 \pm 2.4 \text { for asthma group } \\
8.9 \pm 2.8 \text { for control group }\end{array}$ & $\begin{array}{l}\text { Inclusion: diagnosed stable asthma; able to cooperate and comply with pulmonary function tests } \\
\text { Exclusion: restrictive ventilation dysfunction; history of calcium supplementation; recently taken vitamin D; serious } \\
\text { diseases }\end{array}$ \\
\hline [49] & $156(65)$ & $13.8 \pm 2.4$ & $\begin{array}{l}\text { Inclusion: Chinese ethnicity; aged 8-18 years; receipt of dialysis therapy for at least } 3 \text { months; hospitalization within } 14 \\
\text { days (exclusive of a hospital stay for dialysis) } \\
\text { Exclusion: severe visual or auditory impairment or mental retardation; renal transplant recipients; history of } \\
\text { psychiatric disorders including anxiety and depression; malignancy /leukaemia; chronic hepatic disease; autoimmune } \\
\text { diseases or active infections; significant life event unrelated to their renal disease in the past } 30 \text { days (e.g., severe illness } \\
\text { of a family member, family structure changes, losing a family member, changing the living place); osteoporosis or } \\
\text { receiving supplementation with ergocalciferol or cholecalciferol }\end{array}$ \\
\hline [50] & $270(145)$ & $\begin{array}{l}12.1 \pm 2.6 \text { for male depressive disorder group } \\
11.6 \pm 2.8 \text { for male control group } \\
12.0 \pm 2.7 \text { for female depressive disorder group } \\
12.3 \pm 2.8 \text { for female control group }\end{array}$ & $\begin{array}{l}\text { Inclusion: aged 8-16 years; BMI ranging from the } 5 \text { th to } 95 \text { th percentiles; depressive disorders diagnosed by local } \\
\text { psychiatrists (for depressive disorder group) } \\
\text { Exclusion: suicidal ideation; receiving medical treatments that could affect thyroid function in the preceding } 2 \text { months }\end{array}$ \\
\hline [51] & 36 & $\begin{array}{l}14.0 \pm 2.4 \text { for non-mood disorders group } \\
14.1 \pm 1.2 \text { for major mood disorders group } \\
13.9 \pm 2.0 \text { for bipolar disorder group }\end{array}$ & $\begin{array}{l}\text { Inclusion: adolescents enrolled in the National Institute of Mental Health (NIMH) Longitudinal Assessment of Manic } \\
\text { Symptoms (LAMS) study; mood symptom changes and elevated symptoms of mania biannually } \\
\text { Exclusion: - }\end{array}$ \\
\hline [53] & $82(42)$ & $\begin{array}{l}14.7 \pm 2.3 \text { for obsessive compulsive disorder group } \\
14.2 \pm 2.6 \text { for control group }\end{array}$ & $\begin{array}{l}\text { Inclusion: patient of the outpatient clinic for children and adolescent psychiatry at Ordu University Research and } \\
\text { Training Hospital; diagnosis according to DSM-V criteria (for obsessive compulsive disorder group); minor issues (for } \\
\text { control group) } \\
\text { Exclusion: infections; psychotic disorders; diagnosis of mental retardation and developmental disorders; nutritional } \\
\text { support product used in the previous year; vegetarians }\end{array}$ \\
\hline [54] & $9068(4445)$ & $3.0-17.9$ & $\begin{array}{l}\text { Inclusion: aged } 3-17.9 \text { years } \\
\text { Exclusion: missing data }\end{array}$ \\
\hline
\end{tabular}


Table 7. Cont.

\begin{tabular}{|c|c|c|c|}
\hline Ref. & $\begin{array}{l}\text { Number of Participants } \\
\text { (Girls) }\end{array}$ & Age (Mean with SD/Range) & Inclusion Criteria/Exclusion Criteria \\
\hline [55] & $217(105)$ & $12.0 \pm 2.9$ & $\begin{array}{l}\text { Inclusion: patients attending a Pediatric Center for Weight Management Treatment Centre in Alberta, Canada; aged } \\
\text { 2-18 years; overweight (BMI between the 85th and 97th percentile) or obesity (BMI above the 97th percentile) } \\
\text { Exclusion: missing data * }\end{array}$ \\
\hline [56] & $138(69)$ & $\begin{array}{l}12.8 \pm 1.9 \text { for depression group } \\
12.7 \pm 1.8 \text { for control group }\end{array}$ & $\begin{array}{l}\text { Inclusion: patients of Adolescent Clinic and Child Psychiatry Clinic of the Medical School of Dicle University } \\
\text { Exclusion: missing data }\end{array}$ \\
\hline [57] & $5066(2481)$ & $\begin{array}{l}14.7 \pm 2.0 \text { for males } \\
14.6 \pm 2.0 \text { for females }\end{array}$ & $\begin{array}{l}\text { Inclusion: aged } 11-17 \text { years } \\
\text { Exclusion: missing data }\end{array}$ \\
\hline [58] & $1095(527)$ & $14.7 \pm 2.6$ & $\begin{array}{l}\text { Inclusion: students; aged 10-18 years; selected randomly by multistage random cluster sampling } \\
\text { Exclusion: - }\end{array}$ \\
\hline [59] & $38(20)$ & $12.1 \pm 3.1$ & $\begin{array}{l}\text { Inclusion: aged 7-17 years; proven diagnosis of cystic fibrosis via sweat test (sweat } \mathrm{Cl}>60 \mathrm{mmol} / \mathrm{L} \text { ) } \\
\text { Exclusion: no exclusion criteria * }\end{array}$ \\
\hline [60] & $65(33)$ & $\begin{array}{l}16.8 \pm 1.5 \text { for male major depressive disorder group } \\
16.4 \pm 2.0 \text { for male control group } \\
16.6 \pm 1.4 \text { for female major depressive disorder } \\
\text { group } \\
16.3 \pm 2.2 \text { for female control group }\end{array}$ & $\begin{array}{l}\text { Inclusion: outpatients from the Massachusetts General Hospital for Children, BMI between the 5th and 95th percentiles } \\
\text { for age; being referred by local psychiatrists (for major depressive disorder group) } \\
\text { Exclusion: medical conditions or medications that could affect bone metabolism (including estrogen/progesterone or } \\
\text { glucocorticoids) within the preceding } 3 \text { months; any other axis I disorder except for co-morbid anxiety; suicidal } \\
\text { ideation }\end{array}$ \\
\hline [61] & $104(75)$ & $15.4 \pm 1.6$ & $\begin{array}{l}\text { Inclusion: patients of the Strong Behavioral Health Child and Adolescent Acute Inpatient Service or Partial } \\
\text { Hospitalization Service (CAPHS), Department of Psychiatry, University of Rochester; acute mental health treatment } \\
\text { over a 16-month period } \\
\text { Exclusion: - }\end{array}$ \\
\hline [62] & $2413(1306) *$ & $9.9 \pm 1.1$ & $\begin{array}{l}\text { Inclusion: participant of the Avon Longitudinal Study of Parents and Children (ALSPAC) cohort from South West } \\
\text { England (single and twin births born between } 1 \text { April 1991, and } 31 \text { December 1992) } \\
\text { Exclusion: any previous behavioral problems at the age of } 7 \text { or 9; missing data }\end{array}$ \\
\hline [63] & 2759 & $\begin{array}{l}9.8 \text { for vitamin } \mathrm{D} \text { assessment } \\
10.6 \text { and } 13.8 \text { for depressive symptoms assessment }\end{array}$ & $\begin{array}{l}\text { Inclusion: participant of the ALSPAC cohort from South West England (single and twin births born between } 1 \text { April } \\
\text { 1991, and } 31 \text { December 1992) } \\
\text { Exclusion: - }\end{array}$ \\
\hline
\end{tabular}

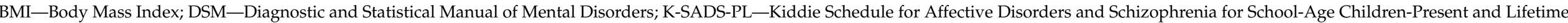

Episode; *-data provided on request. 
Table 8. The exposure, intervention and outcome of the included observational studies.

\begin{tabular}{|c|c|c|c|}
\hline Ref. & Exposure & Outcome & Psychological Measure \\
\hline [47] & $25(\mathrm{OH})$ cholecalciferol level in blood & Behavior problems & $\begin{array}{l}\text { Child Behavior Checklist (CBCL) } \\
\text { Youth Self-Report (YSR) }\end{array}$ \\
\hline [48] & $25(\mathrm{OH})$ cholecalciferol level in blood & Quality of life & $\begin{array}{l}\text { Activity of Daily Living (ADL) score } \\
\text { Medical Research Council (MRC) score }\end{array}$ \\
\hline [49] & $25(\mathrm{OH})$ cholecalciferol level in blood & Anxiety symptoms & Screen for Child Anxiety Related Emotional Disorders-Chinese version (SCARED) \\
\hline [50] & $25(\mathrm{OH})$ cholecalciferol level in blood & Depressive symptoms & $\begin{array}{l}\text { 1-item self-reported mental health questionnaire (feeling despair and/or sad continuously for more } \\
\text { than } 2 \text { weeks to a point that interferes with normal study and life) }\end{array}$ \\
\hline [51] & $25(\mathrm{OH})$ cholecalciferol level in blood & Bipolar disorder and major depressive disorder & $\begin{array}{l}\text { Kiddie Schedule for Affective Disorders and Schizophrenia for School-Age Children-Present and } \\
\text { Lifetime Episode - Version Plus (K-SADS-PL-W) }\end{array}$ \\
\hline [52] & $25(\mathrm{OH})$ cholecalciferol level in blood & $\begin{array}{l}\text { Psychopathologies } \\
\text { Severity of obsessive compulsive disorder } \\
\text { Depression }\end{array}$ & $\begin{array}{l}\text { Kiddie Schedule for Affective Disorders and Schizophrenia for School-Age Children-Present and } \\
\text { Lifetime Version (K-SADS-PL) for DSM-IV diagnostic criteria } \\
\text { Children's Yale Brown Obsession Compulsion Scale (CYBOCS) } \\
\text { Children's Depression Inventory (CDI) }\end{array}$ \\
\hline [53] & $25(\mathrm{OH})$ cholecalciferol level in blood & $\begin{array}{l}\text { Severity of obsessive compulsive disorder } \\
\text { Depression } \\
\text { Anxiety }\end{array}$ & $\begin{array}{l}\text { Yale-Brown Obsessive Compulsive Scale (Y-BOCS) } \\
\text { Children's Depression Inventory (CDI) } \\
\text { State-Trait Anxiety Inventory } 1 \text { and } 2 \text { (STAI-1 and STAI-2) }\end{array}$ \\
\hline [54] & $25(\mathrm{OH})$ cholecalciferol level in blood & Mental health & Strengths and Difficulties Questionnaire (SDQ) \\
\hline [55] & $25(\mathrm{OH})$ cholecalciferol level in blood & Mental health & DSM-V criteria \\
\hline [57] & $25(\mathrm{OH})$ cholecalciferol level in blood & $\begin{array}{l}\text { Health-Related Quality of Life (HRQoL) } \\
\text { Level of distress }\end{array}$ & $\begin{array}{l}\text { Children's Quality of Life Questionnaire (Kinder-Lebensqualitatsfragebogen, KINDL-R) } \\
\text { Strengths and Difficulties Questionnaire (SDQ) }\end{array}$ \\
\hline [58] & $25(\mathrm{OH})$ cholecalciferol level in blood & Psychiatric distress and violence behaviors & $\begin{array}{l}\text { Global School-based Student Health Survey (GSHS) } \\
\text { Questions about violence }\end{array}$ \\
\hline [59] & $25(\mathrm{OH})$ cholecalciferol level in blood & Depression & Children's Depression Inventory (CDI) \\
\hline [60] & $25(\mathrm{OH})$ cholecalciferol level in blood & Depression & $\begin{array}{l}\text { Children's Depression Inventory (CDI) } \\
\text { Children's Depression Rating Scale-Revised (CDRS-R) }\end{array}$ \\
\hline [61] & $25(\mathrm{OH})$ cholecalciferol level in blood & $\begin{array}{l}\text { Severity of illness, defined by } \\
\text { presence of psychotic features }\end{array}$ & Clinical DSM-IV diagnose \\
\hline [62] & 25(OH)cholecalciferol level in blood & Mental health & Strengths and Difficulties Questionnaire (SDQ) \\
\hline [63] & $25(\mathrm{OH})$ cholecalciferol level in blood & Depressive symptoms & Mood and Feelings Questionnaire (MFQ) \\
\hline
\end{tabular}

DSM—Diagnostic and Statistical Manual of Mental Disorders. 
Table 9. The findings presented in the observational studies included to the systematic review.

\begin{tabular}{|c|c|c|}
\hline Ref. & Observation & Conclusions \\
\hline [47] & $\begin{array}{l}\text { Vitamin D deficiency was associated with an adjusted } 6.0 \text { (95\% CI: } 3.0,9.0) \text { and } 3.4 \text { ( } 95 \% \text { CI: } 0.1 \text {, } \\
\text { 6.6) units higher Child Behavior Checklist and Youth Self-Report externalizing problems scores, } \\
\text { respectively, and an adjusted } 3.6 \text { ( } 95 \% \text { CI: } 0.3,6.9) \text { units higher Child Behavior Checklist } \\
\text { internalizing problems scores. The prevalence of clinical total externalizing problems was } 1.8 \\
(95 \% \text { CI: } 1.1,3.1 \text { ) times higher in children with vitamin D deficiency than that in children } \\
\text { without vitamin D deficiency. }\end{array}$ & $\begin{array}{l}\text { Vitamin D deficiency in middle childhood is related to behavior } \\
\text { problems in adolescence. }\end{array}$ \\
\hline [48] & $\begin{array}{l}\text { Serum 25(OH)D levels were positively correlated with ADL score in children with stable } \\
\text { asthma, and negatively correlated with MRC score. }\end{array}$ & $\begin{array}{l}\text { Increased serum } 25(\mathrm{OH}) \mathrm{D} \text { levels reflect good QoL in children } \\
\text { with stable asthma. }\end{array}$ \\
\hline [49] & $\begin{array}{l}\text { Serum levels of } 25(\mathrm{OH}) \mathrm{D} \text { were significantly lower in patients with anxiety than in normal } \\
\text { controls }(19.4 \pm 10.3 \mathrm{vs} .38 .6 \pm 15.5 \mathrm{ng} / \mathrm{mL}, p<0.001) . \text { Serum } 25(\mathrm{OH}) \mathrm{D} \text { levels }(\leq 15.0 \mathrm{ng} / \mathrm{mL}) \\
\text { were independently associated with the existent of anxiety in children and adolescents } \\
\text { receiving dialysis (OR } 4.650,95 \% \text { CI: } 1.663-13.001, p=0.003) \text {. }\end{array}$ & $\begin{array}{l}\text { Low serum levels of vitamin D are independently associated } \\
\text { with anxiety among children and adolescents on dialysis, which } \\
\text { needs to be confirmed in future experimental and clinical } \\
\text { studies. }\end{array}$ \\
\hline [50] & $\begin{array}{l}\text { Patients with depressive disorder had lower concentrations of } 25(\mathrm{OH}) \mathrm{D}(p<0.005) \text { than control } \\
\text { participants, in both male and female cohorts. However, serum } 25(\mathrm{OH}) \mathrm{D} \text { concentration did not } \\
\text { significantly correlate with depressive symptoms. }\end{array}$ & $\begin{array}{l}\text { Adolescents with depressive disorder have markedly lower } \\
\text { serum } 25(\mathrm{OH}) \mathrm{D} \text { concentrations than control patients. This } \\
\text { relationship is positively associated with disease progression, } \\
\text { suggesting possible nutritional intervention measures for } \\
\text { neuroprotection. }\end{array}$ \\
\hline [51] & $\begin{array}{l}\text { There was no difference between serum vitamin D concentrations in participants from } \\
\text { non-mood control, major mood disorders, and bipolar disorder groups. }\end{array}$ & $\begin{array}{l}\text { There was no difference between serum vitamin D } \\
\text { concentrations in participants from non-mood control, major } \\
\text { mood disorders, and bipolar disorder groups. }\end{array}$ \\
\hline [52] & $\begin{array}{l}\text { Vitamin D levels were lower in patients diagnosed with OCD }(15.88 \pm 6.96 \mathrm{ng} / \mathrm{mL}) \text { when } \\
\text { compared to healthy controls }(18.21 \pm 13.24 \mathrm{ng} / \mathrm{mL}) \text {, but the difference was not statistically } \\
\text { significant }(p=0.234) \text {. A negative correlation was found between serum } 25(\mathrm{OH}) \mathrm{D} \text { levels and } \\
\text { obsession scale scores in CYBOCS. }\end{array}$ & $\begin{array}{l}\text { The vitamin D levels of newly diagnosed OCD cases were lower } \\
\text { than that of healthy controls; however, the difference was not } \\
\text { statistically significant. The study does not support presence of a } \\
\text { significant association between serum vitamin D levels and } \\
\text { OCD. }\end{array}$ \\
\hline [53] & $\begin{array}{l}\text { Significantly lower levels of vitamin D in the patient group compared to control group } \\
(p<0.001) \text { were observed. }\end{array}$ & Vitamin D deficiency can play a role in the etiology of OCD. \\
\hline
\end{tabular}


Table 9. Cont.

Ref

\section{Observation}

There were inverse associations between $25(\mathrm{OH}) \mathrm{D}$ concentrations and the subscales emotional problems, peer relationship problems and the total difficulties score in both genders after adjustment for potential confounders. The strongest associations were observed in the older subsample for parent-ratings in boys and self-ratings in girls. In the younger subsample the associations were less strong and no longer evident after adjustment for potential confounders such as migration background, socioeconomic status and frequency of playing outside.

[55] No relationships between mental health parameters (type or total) and vitamin D status were observed

[56] Negative correlation was found between the vitamin D levels and depression score in the group with depression $(\mathrm{r}=-0.368 ; p=0.03)$

Bivariate analyses demonstrated a significant positive association between 25(OH)D and HRQoL for both self- [estimate $(\mathrm{E})=0.82,95 \% \mathrm{CI} 0.35-1.30, p=0.001$ ] and parent ratings $(\mathrm{E}=1.33,95 \% \mathrm{CI} 0.83-1.83$, $p<0.001)$. In addition, negative correlations between $25(\mathrm{OH}) \mathrm{D}$ and self $(\mathrm{E}=-0.34,95 \% \mathrm{CI}-0.58$ to -0.11 $p=0.005)$ and parent-reported total SDQ scores $(\mathrm{E}=-0.70,95 \% \mathrm{CI}-1.03$ to $-0.37, p<0.001)$ were found. Generalized linear models adjusted for age, sex, BMI, systolic blood pressure, migration background, socio-economic status, and sedentary screen time confirmed that $25(\mathrm{OH}) \mathrm{D}$ independently and significantly predicted better HRQoL $(p \leq 0.004)$

The prevalence of self-reported anger, anxiety, poor quality sleep, sadness/depression, and worry was significantly lower in vitamin D sufficient participants compared with their other counterparts. The odds of reporting anger, anxiety, poor quality sleep, and worry, increased approximately 1.5 to 1.8 times in vitamin D insufficient compared with normal children and adolescents. Risk estimates indicated that

vitamin D insufficient and deficient subjects had higher odds of reporting worry compared to normal vitamin D group [OR = 2.417 (95\% CI: 1.483-3.940) for vitamin D insufficient students, and OR = 2.209 (95\% CI: 1.351-3.611) for vitamin D deficient students] ( $p$-trend $=0.001)$. Violence behaviors did not show any association with vitamin D status $(p>0.05)$.

\section{Conclusions}

Based on the large-scale cross-sectional study in a German population-based sample of children and adolescents inverse associations between $25(\mathrm{OH}) \mathrm{D}$ concentrations and both parent- and self-rated SDQ scores of the total difficulties scale and different subscales with the strongest association in the subsample aged 12-18 years for both genders were detected.

The influence of vitamin D status on mental health may extend beyond mental health disease type to disease severity, because disease expression may change with overall child development.

Even if clinical depression is absent, the frequency of depressive symptoms is increased with decreased vitamin D levels, independent of other factors. Maintaining vitamin D support during adolescence, as with the first year of life, is necessary for both the prevention and treatment of depression.

These findings linking $25(\mathrm{OH}) \mathrm{D}$ to better well-being in a nationally representative sample of German children and adolescents suggest beneficial effects of vitamin D on mental health. However, recommendations for vitamin supplementation in healthy children and adolescents are not warranted from the data.

Some psychiatric distress such as anger, anxiety, poor quality sleep, depression, and worry are associated with hypovitaminosis D in adolescents. 
Table 9. Cont.

Ref Observation

Serum 25(OH)D was negatively associated with CDI scores $(r=-0.55, p<0.001)$, and the group of

[59] patients with insufficient 25(OH)D levels indeed reported significantly more depressive symptoms $(\mathrm{t}=4.26 ; p<0.001)$

The 25(OH)D did not differ in girls with MDD compared to controls, even after adjusting for BMI, lean mass and bone age. Vitamin D levels were not significantly different in MDD compared to controls even

[60] after adjusting for BMI. Vitamin D was significantly higher in girls with MDD as compared to controls (MDD: $33.5 \pm 8.1$ versus healthy controls: $22.5 \pm 8.0 \mathrm{ng} / \mathrm{mL} ; p<0.001$ ), and this difference remained statistically significant after adjusting for BMI $(p=0.001)$.

Adolescents with psychotic features had lower vitamin D levels than those without $(20.4 \mathrm{ng} / \mathrm{mL}$ vs. $24.7 \mathrm{ng} / \mathrm{mL} ; p=0.04,1 \mathrm{df})$. The association for vitamin D deficiency and psychotic features was substantial (OR $3.5 ; 95 \%$ CI $1.4-8.9 ; p<0.009$ )

Higher 25(OH)D3 concentrations were weakly associated with lower risk of prosocial problems (fully

[62] adjusted OR 95\% CI $0.85(0.74,0.98)$ ). Serum $25(\mathrm{OH}) \mathrm{D} 3$ or $25(\mathrm{OH}) \mathrm{D} 2$ concentrations were not associated with other subscales of SDQ or total difficulties score after adjusting for confounders and other measured analytes related to vitamin $\mathrm{D}$.

Higher concentrations of 25(OH)D3 assessed at mean age 9.8 years were associated with lower levels of depressive symptoms at age 13.8 years [adjusted RR; $95 \%$ CI: 0.90 (0.86-0.95)], but not at age 10.6 years

[63] [adjusted RR 95\% CI: $0.98(0.93-1.03)]$ and with increased odds of decreasing symptoms between age 10.6 and 13.8 years [adjusted RR 95\% CI: 1.08 (1.01-1.16)]. Serum 25(OH)D2 concentrations were not associated with depressive symptoms.

\section{Conclusions}

The 25(OH)D insufficiency was associated with depressive symptoms in this cohort of youth with CF. Future rigorous studies investigating vitamin $\mathrm{D}$ and depression in $\mathrm{CF}$ are warranted with larger sample sizes using confirmatory methods to diagnose depressive disorders.

Vitamin D was significantly higher in girls with MDD as compared to controls, but did not differ for other comparisons.

Vitamin D deficiency and insufficiency are both highly prevalent in adolescents with severe mental illness.

The findings do not support the hypothesis that $25(\mathrm{OH})$ cholecalciferol status in childhood has important influences on behavioral traits in humans.

The association between vitamin D level and depressive symptoms is independent of a wide range of potential confounding factors, and appears to be stronger with greater time separation between assessment of $25(\mathrm{OH}) \mathrm{D}$ and assessment of depressive symptoms.

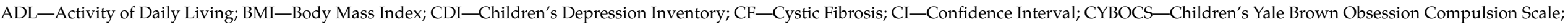

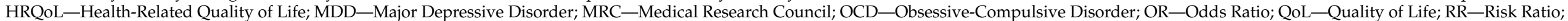

SDQ — Strengths and Difficulties Questionnaire. 


\subsection{Summary}

The summary of observations and conclusions for included studies of association between vitamin D and mental health, with the total NOS score are described in Table 10. It was observed that for the vast majority of included studies, both intervention and observational ones, the results supported beneficial association. Only in case of 2 studies, no effect of vitamin $\mathrm{D}$ was stated for bipolar disorder and major depressive disorder [51] and mental health (assessed using DSM-V criteria) [55]. In case of three studies the effect of vitamin D was inconclusive, as it was observed only for some of applied analysis $[50,60]$ or depending on the studied component of obsessive compulsive disorder [52]. However, while the total NOS score is taken into account, it should be indicated that all the studies of low risk of bias support the positive effect of vitamin D [47,62,63].

Table 10. The summary of observations and conclusions for the included studies of association between vitamin D and mental health, with the total Newcastle-Ottawa Scale (NOS) score.

\begin{tabular}{|c|c|c|c|}
\hline Ref. & Potential Influence of Vitamin D & $\begin{array}{l}\text { Results Supporting/Inconclusive/Not } \\
\text { Supporting Positive Association between } \\
\text { Vitamin D Intake and Mental Health * }\end{array}$ & Quality ** \\
\hline [37] & $\begin{array}{l}\text { Reduced pain, fatigue, and depression, as well as } \\
\text { improved upper-extremity function }\end{array}$ & Supporting & 3 \\
\hline [41] & Reduced some behavioral problems & Supporting & 5 \\
\hline [42] & Reduced depression & Supporting & 4 \\
\hline [43] & $\begin{array}{l}\text { Reduced externalizing behavior problems and } \\
\text { attention deficit and improved cognition }\end{array}$ & Supporting & 3 \\
\hline [44] & Reduced sleep disturbances & Supporting & 4 \\
\hline [45] & Reduced depression and mania & Supporting & 4 \\
\hline [46] & $\begin{array}{l}\text { swings, sleep difficulties, weakness and pain, as well } \\
\text { as improved well-being and ability to concentrate }\end{array}$ & Supporting & 3 \\
\hline [47] & Reduced externalizing and internalizing problems & Supporting & 7 \\
\hline [48] & Improved quality of life & Supporting & 3 \\
\hline [49] & Reduced anxiety & Supporting & 5 \\
\hline [50] & $\begin{array}{l}\text { Reduced/not reduced depression (depending on } \\
\text { analysis) }\end{array}$ & Inconclusive & 4 \\
\hline [51] & $\begin{array}{l}\text { No effect on bipolar disorder and major depressive } \\
\text { disorder }\end{array}$ & Not supporting & 2 \\
\hline$[52]$ & $\begin{array}{l}\text { No effect on obsessive compulsive disorder, but } \\
\text { reduced obsession component }\end{array}$ & Inconclusive & 4 \\
\hline [53] & Reduced obsessive compulsive disorder & Supporting & 5 \\
\hline [54] & $\begin{array}{l}\text { Reduced emotional problems and peer relationship } \\
\text { problems }\end{array}$ & Supporting & 5 \\
\hline [55] & No effect on mental health & Not supporting & 5 \\
\hline [56] & Reduced depression & Supporting & 3 \\
\hline [57] & Reduced distress and improved quality of life & Supporting & 5 \\
\hline [58] & $\begin{array}{l}\text { Reduced anger, anxiety, depression and worry, as } \\
\text { well as improved quality of sleep }\end{array}$ & Supporting & 5 \\
\hline [59] & Reduced depression & Supporting & 4 \\
\hline$[60]$ & $\begin{array}{l}\text { Reduced/not reduced depression (depending on } \\
\text { analysis) }\end{array}$ & Inconclusive & 5 \\
\hline [61] & Reduced psychotic features & Supporting & 5 \\
\hline [62] & Reduced prosocial problems & Supporting & 8 \\
\hline [63] & In longer term reduced depression & Supporting & 7 \\
\hline
\end{tabular}

* Supporting—vitamin D associated with lower risk of mental health problems; not supporting_vitamin D not associated with lower risk of mental health problems; inconclusive-no clear association between vitamin D and risk of mental health problems; ${ }^{* *}$ total score for the NOS.

\section{Discussion}

In spite of the fact that studies of association between vitamin $\mathrm{D}$ and mental health present various studied groups, outcomes and psychological measures, the observed results are consistent and they suggest potential beneficial effect of vitamin D blood level or applied supplementation on mental health. Taking this into account, it may be indicated that regardless of the studied group and studied effect associated with mental health, the vitamin $\mathrm{D}$ is crucial for mental health. 
The association between vitamin $\mathrm{D}$ and mental health was so far studied mainly for depression or depressive symptoms [23-29] and some potential mechanisms explaining the influence of vitamin D were supposed [64]. Vitamin D has potential to cross the blood-brain barrier, to activate receptors in brain cells and to exert its direct impact in the central nervous system [65]. Moreover, there is some evidence for the link between vitamin D and Vitamin D Receptors (VDRs) and the regulation of human behavior, that is strongly suggested by the presence of VDRs in such brain areas as cortex, cerebellum and limbic system [66]. At the same time, Eyles et al. [67] reported that the mechanism potentially important in neuroendocrine functioning may be associated with the VDRs in the hypothalamus. However, it should be also mentioned that VDR genes are polymorphic and their variations occur frequently, what can cause various vitamin D-related dysfunctions [68].

Moreover, studies in animal models indicated potential anti-inflammatory effects of vitamin D administration in hippocampus and hypothalamus and its modulating effects on brain-derived neurotropic factor (BDNF) [65] which may also play a role. Simultaneously, the role of vitamin D may be attributed to its neuroprotective role in the brain which is reflected in modulating neurotrophic signaling [69], and in regulating inflammation by inhibiting proinflammatory cytokines [70].

Taking into account the potential mechanisms described above and the results of the recent studies suggesting beneficial effect of vitamin D on mental health, this area is indicated within the current research perspectives associated with vitamin D [71]. Regardless of the fact, that biological mechanisms linking vitamin D and mental health are still not fully understood [72], it should be indicated that vitamin D may have beneficial effects, which is important considering high prevalence of mental health problems which is not decreasing, despite a substantial increases in the provision of treatment [73]. Taking this into account, improving vitamin D status by applying adequate intake either within a properly balanced diet or as a supplementation, may be beneficial also for the prevention and treatment of mental health problems in children.

The included studies analyzing the association between vitamin $\mathrm{D}$ intake or status and mental health in children assessed various aspects of mental health, so based on the presented observations, it may be suggested that vitamin D is associated with the broad area of mental health with all its elements. However, the limitations of the presented systematic review must be also described. The most important fact results from the limited number of studies published so far, while included studies presented various studied groups, outcomes and psychological measures, so more studies are necessary to deepen the observations. Moreover, since the studies assessed a wide range of possible effects, meta-analysis was impossible [74], so only the systematic review was conducted. Last but not least, only peer-reviewed studies included in databases of PubMed and Web of Science are presented in the systematic review which may have caused that some interesting results are not presented.

At the same time, it should be indicated that some researchers suggest the possible reverse causality in the association between vitamin D and mental health [75]. It results from the fact that some individuals with mental health problems, including depression, may avoid outdoor activity and have poor appetite, resulting in reduced sunlight exposure and consequently reduced endogenous vitamin D synthesis, as well as reduced dietary vitamin $D$ intake [76]. At the same time, they may have increased demand for vitamin $D$ resulting from the disturbed calcium homeostasis [64] observed in patients with mental health problems [77].

Based on the prepared systematic review, vitamin D intake within a properly balanced diet or as a supplementation, except for a safe sun exposure, should be indicated as an element supporting mental health in children, so it should be recommended to meet the required $25(\mathrm{OH})$ cholecalciferol blood level in order to prevent or alleviate mental health problems. 


\section{Conclusions}

The vast majority of assessed studies, including the most prominent ones (based on the NOS score) supported potential positive influence of vitamin D on mental health in children. Vitamin D intake within a properly balanced diet or as a supplementation, except for a safe sun exposure, should be indicated as an element supporting mental health in children, so it should be recommended to meet the required 25(OH)cholecalciferol blood level in order to prevent or alleviate mental health problems.

Author Contributions: Conceptualization, D.G. (Dominika Głabska) and D.G. (Dominika Guzek); methodology, D.G. (Dominika Głąbska) and D.G. (Dominika Guzek); formal analysis, D.G. (Dominika Głabska), A.K., K.L., D.S., M.S. and D.G. (Dominika Guzek); investigation, D.G. (Dominika Głabska), A.K., K.L., D.S., M.S. and D.G. (Dominika Guzek); writing—original draft preparation, D.G. (Dominika Głabska), A.K., K.L., D.S., M.S. and D.G. (Dominika Guzek); writing-review and editing, D.G. (Dominika Głąska), A.K., K.L., D.S., M.S. and D.G. (Dominika Guzek). All authors have read and agreed to the published version of the manuscript.

Funding: The Polish Ministry of Science and Higher Education within funds of Institute of Human Nutrition Sciences, Warsaw University of Life Sciences (WULS-SGGW).

Institutional Review Board Statement: The literature search was conducted according to the guidelines of the Preferred Reporting Items for Systematic Reviews and Meta-Analyses (PRISMA) and the review was registered in the International Prospective Register of Systematic Reviews (PROSPERO) database (CRD42020155779). The included studies obtained individual approvals from the respective local research ethics committee.

Informed Consent Statement: Not applicable.

Acknowledgments: Nothing to declare.

Conflicts of Interest: The authors declare no conflict of interest.

\section{References}

1. Amrein, K.; Scherkl, M.; Hoffmann, M.; Neuwersch-Sommeregger, S.; Köstenberger, M.; Berisha, A.T.; Martucci, G.; Pilz, S.; Malle, O. Vitamin D deficiency 2.0: An update on the current status worldwide. Eur. J. Clin. Nutr. 2020, 74, 1498-1513. [CrossRef]

2. Cashman, K.D. Vitamin D deficiency: Defining, prevalence, causes, and strategies of addressing. Calcif. Tissue Int. 2020, 106, 14-29. [CrossRef]

3. Institute of Medicine (US). Committee to Review Dietary Reference Intakes for Vitamin D and Calcium. In Dietary Reference Intakes for Calcium and Vitamin D; The National Academies Collection: Reports funded by National Institutes of Health; Ross, A.C., Taylor, C.L., Yaktine, A.L., Del Valle, H.B., Eds.; National Academies Press (US): Washington, DC, USA, 2011.

4. Aspray, T.J.; Bowring, C.; Fraser, W.; Gittoes, N.; Javaid, M.K.; Macdonald, H.; Patl, S.; Selby, P.; Tanna, N.; Francis, R.M. National osteoporosis society vitamin D guideline summary. Age Ageing 2014, 43, 592-595. [CrossRef] [PubMed]

5. Holick, M.F.; Binkley, N.C.; Bischoff-Ferrari, H.A.; Gordon, C.M.; Hanley, D.A.; Heaney, R.P.; Murad, M.H.; Weaver, C.M. Evaluation, treatment, and prevention of vitamin d deficiency: An endocrine society clinical practice guideline. J. Clin. Endocrinol. Metab. 2011, 96, 1911-1930. [CrossRef] [PubMed]

6. EFSA Panel on Dietetic Products, Nutritions and Allergies (NDA). Dietary reference values for vitamin D. EFSA J. 2016, 14, e04547. [CrossRef]

7. Cashman, K.D.; Dowling, K.G.; Škrabáková, Z.; Gonzalez-Gross, M.; Valtueña, J.; De Henauw, S.; Moreno, L.; Damsgaard, C.T.; Michaelsen, K.F.; Mølgaard, C.; et al. Vitamin D deficiency in Europe: Pandemic? Am. J. Clin. Nutr. 2016, 103, 1033-1044. [CrossRef]

8. Spiro, A.; Buttriss, J.L. Vitamin D: An overview of vitamin D status and intake in Europe. Nutr. Bull. 2014, 39, 322-350. [CrossRef] [PubMed]

9. Palaniswamy, S.; Hyppönen, E.; Williams, D.M.; Jokelainen, J.; Lowry, E.; Keinänen-Kiukaanniemi, S.; Herzig, K.H.; Järvelin, M.R.; Sebert, S. Potential determinants of vitamin D in Finnish adults: A cross-sectional study from the Northern Finland birth cohort 1966. Br. Med. J. Open 2017, 7, e013161. [CrossRef]

10. Jääskeläinen, T.; Itkonen, S.T.; Lundqvist, A.; Erkkola, M.; Koskela, T.; Lakkala, K.; Dowling, K.G.; Hull, G.L.; Kröger, H.; Karppinen, J.; et al. The positive impact of general vitamin D food fortification policy on vitamin D status in a representative adult Finnish population: Evidence from an 11-y follow-up based on standardized 25-hydroxyvitamin D data. Am. J. Clin. Nutr. 2017, 105, 1512-1520. [CrossRef]

11. Eleni, A.; Panagiotis, P. A systematic review and meta-analysis of vitamin D and calcium in preventing osteoporotic fractures. Clin. Rheumatol. 2020, 39, 3571-3579. [CrossRef] 
12. Zhang, Y.; Fang, F.; Tang, J.; Jia, L.; Feng, Y.; Xu, P.; Faramand, A. Association between vitamin D supplementation and mortality: Systematic review and meta-analysis. Br. Med. J. 2019, 366. [CrossRef]

13. Garland, C.F.; Kim, J.J.; Mohr, S.B.; Gorham, E.D.; Grant, W.B.; Giovannucci, E.L.; Baggerly, L.; Hofflich, H.; Ramsdell, J.W.; Zeng, K.; et al. Meta-analysis of all-cause mortality according to serum 25-hydroxyvitamin D. Am. J. Public Health 2014, 104, e43-e50. [CrossRef] [PubMed]

14. Bahrami, L.S.; Ranjbar, G.; Norouzy, A.; Arabi, S.M. Vitamin D supplementation effects on the clinical outcomes of patients with coronary artery disease: A systematic review and meta-analysis. Sci. Rep. 2020, 10, 1-10. [CrossRef]

15. Zhang, Y.; Tan, H.; Tang, J.; Li, J.; Chong, W.; Hai, Y.; Feng, Y.; Lunsford, L.D.; Xu, P.; Jia, D.; et al. Effects of vitamin D supplementation on prevention of type 2 diabetes in patients with prediabetes: A systematic review and meta-analysis. Diabetes Care 2020, 43, 1650-1658. [CrossRef] [PubMed]

16. Jolliffe, D.A.; Camargo, C.A.; Sluyter, J.D.; Aglipay, M.; Aloia, J.F.; Ganmaa, D.; Bergman, P.; Borzutzky, A.; Damsgaard, C.T.; Dubnov-Raz, G.; et al. Vitamin D supplementation to prevent acute respiratory infections: Systematic review and meta-analysis of aggregate data from randomised controlled trials. MedRxiv 2020. [CrossRef]

17. Wu, Z.; Malihi, Z.; Stewart, A.W.; Lawes, C.M.; Scragg, R. Effect of vitamin D supplementation on pain: A systematic review and meta-analysis. Pain Physician 2016, 19, 415-427. [PubMed]

18. Liampas, I.; Siokas, V.; Brotis, A.; Dardiotis, E. Vitamin D serum levels in patients with migraine: A meta-analysis. Rev. Neurol. 2020, 176, 560-570. [CrossRef]

19. Liu, N.; Sun, J.; Wang, X.; Zhang, T.; Zhao, M.; Li, H. Low vitamin D status is associated with coronavirus disease 2019 outcomes: A systematic review and meta-analysis. Int. J. Infect. Dis. 2021, 2, 58-64. [CrossRef]

20. Pereira, M.; Dantas Damascena, A.; Galvão Azevedo, L.M.; de Almeida Oliveira, T.; da Mota Santana, J. Vitamin D deficiency aggravates COVID-19: Systematic review and meta-analysis. Crit. Rev. Food Sci. Nutr. 2020, 4, 1-9. [CrossRef]

21. Cheng, Y.C.; Huang, Y.C.; Huang, W.L. The effect of vitamin D supplement on negative emotions: A systematic review and meta-analysis. Depress. Anxiety 2020, 37, 549-564. [CrossRef]

22. Hoffmann, M.R.; Senior, P.A.; Mager, D.R. Vitamin D supplementation and health-related quality of life: A systematic review of the literature. J. Acad. Nutr. Diet. 2015, 115, 406-418. [CrossRef] [PubMed]

23. Gowda, U.; Mutowo, M.P.; Smith, B.J.; Wluka, A.E.; Renzaho, A.M. Vitamin D supplementation to reduce depression in adults: Meta-analysis of randomized controlled trials. Nutrition 2015, 31, 421-429. [CrossRef] [PubMed]

24. Li, G.; Mbuagbaw, L.; Samaan, Z.; Falavigna, M.; Zhang, S.; Adachi, J.D.; Cheng, J.; Papaioannou, A.; Thabane, L. Efficacy of vitamin D supplementation in depression in adults: A systematic review. J. Clin. Endocrinol. Metab. 2014, 99, 757-767. [CrossRef]

25. Spedding, S. Vitamin D and depression: A systematic review and meta-analysis comparing studies with and without biological flaws. Nutrients 2014, 6, 1501-1518. [CrossRef]

26. Vellekkatt, F.; Menon, V. Efficacy of vitamin D supplementation in major depression: A meta-analysis of randomized controlled trials. J. Postgrad. Med. 2019, 65, 74-80. [CrossRef]

27. Anglin, R.E.S.; Samaan, Z.; Walter, S.D.; McDonald, S.D. Vitamin D deficiency and depression in adults: Systematic review and meta-analysis. Br. J. Psychiatry 2013, 202, 100-107. [CrossRef] [PubMed]

28. Ju, S.Y.; Lee, Y.J.; Jeong, S.N. Serum 25-hydroxyvitamin D levels and the risk of depression: A systematic review and meta-analysis. J. Nutr. Health Aging 2013, 17, 447-455. [CrossRef]

29. Shaffer, J.A.; Edmondson, D.; Taggart Wasson, L.; Falzon, L.; Homma, K.; Ezeokoli, N.; Li, P.; Davidson, K.W. Vitamin D supplementation for depressive symptoms: A systematic review and meta-analysis of randomized controlled trials. Psychosom. Med. 2014, 76, 190-196. [CrossRef]

30. World Health Organization. Promoting Mental Health. Concepts, Emerging, Evidence. Practice Summary Report; World Health Organization: Geneva, Switzerland, 2004.

31. Głabska, D.; Guzek, D.; Groele, B.; Gutkowska, K. Fruit and vegetable intake and mental health in adults: A systematic review. Nutrients 2020, 12, 115. [CrossRef]

32. García-Carrión, R.; Villarejo-Carballido, B.; Villardón-Gallego, L. Children and adolescents mental health: A systematic review of interaction-based interventions in schools and communities. Front. Psychol. 2019, 10, 918. [CrossRef]

33. Zhang, M.; Cheng, K.; Rope, R.; Martin, E.; Jetmalani, A. Do children with mental disorders have higher prevalence of hypovitaminosis D? F1000Res 2013, 17, 159. [CrossRef]

34. Föcker, M.; Antel, J.; Ring, S.; Hahn, D.; Kanal, Ö.; Öztürk, D.; Hebebrand, J.; Libuda, L. Vitamin D and mental health in children and adolescents. Eur. Child. Adolesc. Psychiatry 2017, 26, 1043-1066. [CrossRef]

35. Moher, D.; Liberati, A.; Tetzlaff, J.; Altman, D.G.; PRISMA Group. Preferred reporting items for systematic reviews and meta-analyses: The PRISMA statement. PLoS Med. 2009, 6, e1000097. [CrossRef] [PubMed]

36. Dougherty, K.A.; Bertolaso, C.; Schall, J.I.; Smith-Whitley, K.; Stallings, V.A. Vitamin D supplementation improves health related quality of life in children with sickle cell disease. Med. Sci. Sports. Exerc. 2018, 50, 729-730. [CrossRef]

37. Dougherty, K.A.; Schall, J.I.; Bertolaso, C.; Smith-Whitley, K.; Stallings, V.A. Vitamin D supplementation improves health-related quality of life and physical performance in children with sickle cell disease and in healthy children. J. Pediatr. Health Care 2020, 34, 424-434. [CrossRef]

38. Assessing Risk of Bias in Non-Randomized Studies. Chapter 13.5.2.3. Available online: http://handbook-5-1.cochrane.org/ (accessed on 4 February 2021). 
39. Wells, G.A.; Shea, B.; O'Connell, D.; Peterson, J.; Welch, V.; Losos, M.; Tugwell, P. The Newcastle-Ottawa Scale (NOS) for Assessing the Quality of Nonrandomised Studies in Meta-Analyses. Available online: http://www.ohri.ca/programs/clinical_ epidemiology / oxford.asp (accessed on 4 February 2021).

40. You, S.; Kong, T.H.; Han, W. The Effects of short-term and long-term hearing changes on music exposure: A systematic review and meta-analysis. Int. J. Environ. Res. Public Health 2020, 17, 2091. [CrossRef] [PubMed]

41. Naeini, A.A.; Fasihi, F.; Najafi, M.; Ghazvini, M.R.; Hasanzadeh, A. The effects of vitamin D supplementation on ADHD (Attention Deficit Hyperactivity Disorder) in 6-13 year-old students: A randomized, double-blind, placebo-controlled study. Eur. J. Integr. Med. 2019, 25, 28-33. [CrossRef]

42. Bahrami, A.; Mazloum, S.R.; Maghsoudi, S.; Soleimani, D.; Khayyatzadeh, S.S.; Arekhi, S.; Arya, A.; Mirmoosavi, S.J.; Ferns, G.A.; Bahrami-Taghanaki, H.; et al. High dose vitamin D supplementation is associated with a reduction in depression score among adolescent girls: A nine-week follow-up study. J. Diet. Suppl. 2018, 15, 173-182. [CrossRef] [PubMed]

43. Grung, B.; Sandvik, A.M.; Hjelle, K.; Dahl, L.; Frøyland, L.; Nygård, I.; Hansen, A.L. Linking vitamin D status, executive functioning and self-perceived mental health in adolescents through multivariate analysis: A randomized double-blind placebo control trial. Scand. J. Psychol. 2017, 58, 123-130. [CrossRef] [PubMed]

44. Guler, S.; Yesil, G.; Ozdil, M.; Onal, H. Sleep disturbances and serum vitamin D levels in children with autism spectrum disorder. Int. J. Clin. Exp. Med. 2016, 9, 14691-14697.

45. Sikoglu, E.M.; Navarro, A.A.; Starr, D.; Dvir, Y.; Nwosu, B.U.; Czerniak, S.M.; Rogan, R.C.; Castro, M.C.; Edden, R.A.; Frazier, J.A.; et al. Vitamin D3 supplemental treatment for mania in youth with bipolar spectrum disorders. J. Child Adolesc. Psychopharmacol. 2015, 25, 415-424. [CrossRef] [PubMed]

46. Högberg, G.; Gustafsson, S.A.; Hällström, T.; Gustafsson, T.; Klawitter, B.; Petersson, M. Depressed adolescents in a case-series were low in vitamin D and depression was ameliorated by vitamin D supplementation. Acta Paediatr. 2012, 101, 779-783. [CrossRef] [PubMed]

47. Robinson, S.L.; Marín, C.; Oliveros, H.; Mora-Plazas, M.; Lozoff, B.; Villamor, E. Vitamin D deficiency in middle childhood is related to behavior problems in adolescence. J. Nutr. 2020, 1, 140-148. [CrossRef] [PubMed]

48. Bai, Y.J.; Dai, R.J. Serum levels of vitamin A and 25-hydroxyvitamin D3 (25OHD3) as reflectors of pulmonary function and quality of life (QOL) in children with stable asthma: A case-control study. Medicine 2018, 97, e9830. [CrossRef] [PubMed]

49. Han, B.; Zhu, F.X.; Yu, H.F.; Liu, S.; Zhou, J.L. Low serum levels of vitamin D are associated with anxiety in children and adolescents with dialysis. Sci. Rep. 2018, 8, 5956. [CrossRef]

50. Huang, W.; Gong, D.; Bao, Y. Urinary iodine and serum 25-hydroxyvitamin D are associated with depression in adolescents. Trop. J. Pharm. Res. 2018, 17, 2471-2476. [CrossRef]

51. Petrov, B.; Aldoori, A.; James, C.; Yang, K.; Algorta, G.P.; Lee, A.; Zhang, L.; Lin, T.; Awadhi, R.A.; Parquette, J.R.; et al. Bipolar disorder in youth is associated with increased levels of vitamin D-binding protein. Transl. Psychiatry 2018, 8, 61. [CrossRef]

52. Yazici, K.U.; Percinel Yazici, I.; Ustundag, B. Vitamin D levels in children and adolescents with obsessive compulsive disorder. Nord. J. Psychiatry 2018, 72, 173-178. [CrossRef]

53. Esnafoğlu, E.; Yaman, E. Vitamin B12, folic acid, homocysteine and vitamin D levels in children and adolescents with obsessive compulsive disorder. Psychiatry Res. 2017, 254, 232-237. [CrossRef]

54. Husmann, C.; Frank, M.; Schmidt, B.; Jöckel, K.H.; Antel, J.; Reissner, V.; Libuda, L.; Hebebrand, J.; Föcker, M. Low 25(OH)vitamin D concentrations are associated with emotional and behavioral problems in German children and adolescents. PLoS ONE 2017, 12, e0183091. [CrossRef]

55. MacDonald, K.; Godziuk, K.; Yap, J.; LaFrance, R.; Ansarian, M.; Haqq, A.; Mager, D.R. Vitamin D status, cardiometabolic, liver, and mental health status in obese youth attending a pediatric weight management center. J. Pediatr. Gastroenterol. Nutr. 2017, 65, 462-466. [CrossRef] [PubMed]

56. Karabel, M.; Şimşek, S.; Haspolat, Y.K.; Kelekçi, S.; Karabel, D.; Tuncel, T.; Şen, V.; Uluca, U.; Tan, I.; Şahin, C. The association between depression and vitamin D and parathyroid hormone levels in adolescents. Int. J. Pediatr. 2016, 4, $1365-1372$.

57. Schäfer, T.K.; Herrmann-Lingen, C.; Meyer, T. Association of circulating 25-hydroxyvitamin D with mental well-being in a population-based, nationally representative sample of German adolescents. Qual. Life Res. 2016, 25, 3077-3086. [CrossRef] [PubMed]

58. Ataie-Jafari, A.; Qorbani, M.; Heshmat, R.; Ardalan, G.; Motlagh, M.E.; Asayesh, H.; Arzaghi, S.M.; Tajadini, M.H.; Nejatinamini, S.; Poursafa, P.; et al. The association of vitamin D deficiency with psychiatric distress and violence behaviors in Iranian adolescents: The CASPIAN-III study. J. Diabetes Metab. Disord. 2015, 22, 62. [CrossRef]

59. Smith, B.A.; Cogswell, A.; Garcia, G. Vitamin D and depressive symptoms in children with cystic fibrosis. Psychosomatics 2014, 55, 76-81. [CrossRef] [PubMed]

60. Fazeli, P.K.; Mendes, N.; Russell, M.; Herzog, D.B.; Klibanski, A.; Misra, M. Bone density characteristics and major depressive disorder in adolescents. Psychosom. Med. 2013, 75, 117-123. [CrossRef] [PubMed]

61. Gracious, B.L.; Finucane, T.L.; Friedman-Campbell, M.; Messing, S.; Parkhurst, M.N. Vitamin D deficiency and psychotic features in mentally ill adolescents: A cross-sectional study. BMC Psychiatry 2012, 9, 38. [CrossRef]

62. Tolppanen, A.M.; Sayers, A.; Fraser, W.D.; Lewis, G.; Zammit, S.; Lawlor, D.A. The association of 25-hydroxyvitamin D3 and D2 with behavioural problems in childhood. PLoS ONE 2012, 7, e40097. [CrossRef] 
63. Tolppanen, A.M.; Sayers, A.; Fraser, W.D.; Lewis, G.; Zammit, S.; Lawlor, D.A. The association of serum 25-hydroxyvitamin D3 and D2 with depressive symptoms in childhood-A prospective cohort study. J. Child. Psychol. Psychiatry. 2012, 53, 757-766. [CrossRef]

64. Menon, V.; Kar, S.K.; Suthar, N.; Nebhinani, N. Vitamin D and Depression: A Critical Appraisal of the Evidence and Future Directions. Indian J. Psychol. Med. 2020, 42, 11-21. [CrossRef]

65. Farhangi, M.A.; Mesgari-Abbasi, M.; Nameni, G.; Hajiluian, G.; Shahabi, P. The effects of vitamin D administration on brain inflammatory markers in high fat diet induced obese rats. BMC Neurosci. 2017, 18, 81. [CrossRef]

66. Walbert, T.; Jirikowski, G.F.; Prufer, K. Distribution of 1,25-dihydroxyvitamin D3 receptor immunoreactivity in the limbic system of the rat. Horm. Metab. Res. 2001, 33, 525-531. [CrossRef]

67. Eyles, D.W.; Smith, S.; Kinobe, R.; Hewison, M.; McGrath, J.J. Distribution of the vitamin D receptor and 1 alpha-hydroxylase in human brain. J. Chem. Neuroanat. 2005, 29, 21-30. [CrossRef]

68. Kim, J.S.; Kim, Y.I.; Song, C.; Yoon, I.; Park, J.W.; Choi, Y.B.; Kim, H.T.; Lee, K.S. Association of vitamin D receptor gene polymorphism and Parkinson's disease in Koreans. J. Korean Med. Sci. 2005, 20, 495-498. [CrossRef]

69. Bernd, P. The role of neurotrophins during early development. Gene Expr. 2008, 14, 241-250. [CrossRef]

70. Barker, T.; Martins, T.B.; Hill, H.R.; Kjeldsberg, C.R.; Dixon, B.M.; Schneider, E.D.; Henriksen, V.T.; Weaver, L.K. Circulating proinflammatory cytokines are elevated and peak power output correlates with 25 -hydroxyvitamin $\mathrm{D}$ in vitamin $\mathrm{D}$ insufficient adults. Eur. J. Appl. Physiol. 2013, 113, 1523-1534. [CrossRef] [PubMed]

71. Zhang, R.; Naughton, D.P. Vitamin D in health and disease: Current perspectives. Nutr. J. 2010, 8, 65. [CrossRef] [PubMed]

72. Hossein-Nezhad, A.; Holick, M.F. Vitamin D for health: A global perspective. Mayo Clin. Proc. 2013, 88, 720-755. [CrossRef]

73. Jorm, A.F.; Patten, S.B.; Brugha, T.S.; Mojtabai, R. Has increased provision of treatment reduced the prevalence of common mental disorders? Review of the evidence from four countries. World Psychiatry 2017, 16, 90-99. [CrossRef] [PubMed]

74. Campbell, M.; McKenzie, J.E.; Sowden, A.; Katikireddi, S.V.; Brennan, S.E.; Ellis, S.; Hartmann-Boyce, J.; Ryan, R.; Shepperd, S.; Thomas, J.; et al. Synthesis without meta-analysis (SWiM) in systematic reviews: Reporting guideline. Br. Med. J. 2020, $368,16890$. [CrossRef] [PubMed]

75. Bertone-Johnson, E.R. Vitamin D and the occurrence of depression: Causal association or circumstantial evidence? Nutr. Rev. 2009, 67, 481-492. [CrossRef] [PubMed]

76. Penckofer, S.; Kouba, J.; Byrn, M.; Estwing Ferrans, C. Vitamin D and depression: Where is all the sunshine? Issues Ment. Health Nurs. 2010, 31, 385-393. [CrossRef] [PubMed]

77. Steardo, L., Jr.; Luciano, M.; Sampogna, G.; Carbone, E.A.; Caivano, V.; Di Cerbo, A.; Giallonardo, V.; Palummo, C.; Vece, A.; Del Vecchio, V.; et al. Clinical severity and calcium metabolism in patients with bipolar disorder. Brain Sci. 2020, 10, 417. [CrossRef] [PubMed] 